\title{
THE SECOND STAGE OF SARMATIAN SETTLEMENT IN WALLACHIA
}

The aim of this paper is to discuss the main characteristics of the graves that can be attributed to the second stage of Sarmatian settlement in Wallachia, starting in the last decades of the $2^{\text {nd }}$ century $A D$.

Keywords: Sarmatians, Wallachia, Roman Empire, graves, funerary ritual, grave goods.

Introduction. The present study is a continuation of two previously published articles on the funerary structures attributed to the first stage of arrival of the Sarmatians in Wallachia, in the last decade of the $1^{\text {st }}$ century $\mathrm{AD}$ and the first decades of the $2^{\text {nd }}$ century AD (Oța, Sîrbu 2016a; 2016b). A relatively small number of burials (53 or 54) in Wallachia can be dated to what we have defined on other occasions (Oța, Sîrbu 2009, p. 178-196; 2013, p. 291, 292; 2019a, p. 151-154) as the first stage of penetration of the Sarmatians in Wallachia. The graves, both isolated (seven for certain and three raising doubts) and grouped (43 or 44 graves in six groups) are concentrated in the northeast, east and south of Wallachia (Oța, Sîrbu 2016a, p. 262; 2016b, p. 149).

Second stage of Sarmatian settlement in Wallachia. The second stage of penetration of the Sarmatians in Wallachia, linked to the Marcomannic Wars (Ota 2016, p. 139), begins in the late $2^{\text {nd }}$ century $\mathrm{AD}$ and continues during the following century. There are two explanations for those written above. The first regards the connection between the arrival of the Sarmatians in Wallachia and the Marcomannic Wars, which, in this particular case, should be interpreted differently than it would be assumed at first sight. From the very beginning, the Sarmatians entered Wallachia not as enemies of the Roman Empire, but as allies always supervised by the Roman troops, a hypothesis in support of which five arguments can be invoked: a) the limited total number of Sarmatian discoveries in Wallachia; b) the limited number of the burials in the groups of graves; c) the limited number of tumular burials; d) the fact that the graves in which weapons were deposited are few; e) the territorial distribution of the Sarmatian discoveries in Wallachia, mostly concentrated in areas with significant Roman military presence (Oța 2016, p. 131-135; Oța, Sîrbu 2013, p. 291; 2016c, p. 215, 231). The fact that the five characteristics listed above remain unchanged throughout the entire archaeologically documented Sarmatian presence in Wallachia (late $1^{\text {st }}$ century $\mathrm{AD}$ - late $3^{\text {rd }}$ century $\mathrm{AD}$ ) indicates that the Sarmatians in Wallachia have always been supervised by the Romans, with the Roman control over Wallachia reaching its peak in the first half of the $3^{\text {rd }}$ century $\mathrm{AD}$. As in the first stage, at the end of the $2^{\text {nd }}$ century $\mathrm{AD}$, the Sarmatians entered Wallachia not as enemies of the Romans, but as allies, while their presence can be linked to the needs for supply of the Roman garrisons on the Danubian limes rather than to a form of military support (Oța 2016, p. 138). The second stage of Sarmatian settlement in Wallachia is therefore occasioned by the Marcomannic Wars, but does not properly fall into the category of population movements of the barbaricum and it rather seems to be a consequence of these wars, probably in connection with the need to strengthen the Danubian limes.

The second explanation regards the paradigm of interpreting the Sarmatian discoveries in Wallachia. Generally, even since the Bronze Age, the movements of the steppe populations have been seen as successive waves of newcomers set- 
tling in certain areas (Frachetti 2011, p. 196206; Olbrycht 2000, p. 101-103). Lately, however, this model of explaining the discoveries that can be connected with the steppe populations as a result of periodic population inflows is being challenged, at least regarding the Sarmatian presence in the North-Pontic area (Dan 2017, p. 100; Mordvintseva 2013, p. 205-216; 2015, p. 114). Speaking strictly from the point of view of the Sarmatian discoveries in Wallachia, their grouping in three main chronological stages - the last decade of the $1^{\text {st }}$ century $\mathrm{AD}$ - the first decades of the $2^{\text {nd }}$ century $\mathrm{AD}$; the late $2^{\text {nd }}$ century $\mathrm{AD}-$ the first half of the $3^{\text {rd }}$ century $\mathrm{AD}$; the late $3^{\text {rd }}$ century AD (Oța 2016, p. 135-146; Oța, Sîrbu 2013, p. 291-293; 2019a, p. 151-157) - derives from the dating of the inventory items deposited in the graves, among which the items originating from the Roman Empire have an important role. This pattern of interpretation of the Sarmatian presence in Wallachia in three different chronological stages is based both on the main features of the Sarmatian graves (which are, at least at the moment, almost the only evidence of the presence of the Sarmatians in Wallachia, to which a few discoveries without funerary features are added Sîrbu et al. 2014, p. 94), and on the historical and geographical context of the mentioned area. Regarded as a whole, Wallachia (meaning the territory bordered to the south and the east by the Danube River, to the north by the Southern Carpathians and to the west by the Olt River) is a limited region that is located, unlike other areas inhabited by the Sarmatians, in the immediate vicinity of the Roman Empire, being bordered to the south and the east by the Danubian limes and to the west by the limes alutanus and, certainly starting from the $3^{\text {rd }}$ century $\mathrm{AD}$, by the limes transalutanus (Petolescu 2010, p. 185-188). The hypothesis of a territory controlled at least until the middle of the $3^{\text {rd }}$ century $\mathrm{AD}$ by the Roman troops is in agreement with both the Roman military strategy (for which the limes never represented a barrier in the proper sense of the term Opreanu 1994, p. 212; Opreanu, Lăzărescu 2016, p. 43-48; Tentea 2013, p. 144), and the archaeological discoveries that certify the presence in Wallachia of Roman military detachments that had a surveillance role (Oța 2016, p. 145; 2020, p. 423, 424, 427, 428; Petolescu 2010, p. 187). The Sarmatian communities which the Romans allowed to populate this area were numerically reduced (a fact proved by the limited number of archaeological discoveries and the small number of the graves in groups, the largest number being recorded, so far, in Târgşor, 36 graves - Ciupercă, Măgureanu, Anton 2015, p. 777), with a pastoral economy that depended on the mobility of the herds and the people over varying distances (Bernbeck et al. 2016, p. 52; Kradin 2015, p. 4170; Wendrich, Barnard 2008, p. 5-7). The relatively small number of graves in groups (between a minimum of two and a maximum of 36 burials) and the fact that the burials in a group are not very scattered from a chronological point of view indicate a not so long use of the burial sites, probably a result of the mobility. The fact that this is not a population that penetrated into Wallachia at one single time and remained there for 200 years is proved by the obvious numerical disproportion between the funerary discoveries that can be dated to the first stage of the Sarmatian settlement (53 or 54 graves - Oța, Sîrbu 2016a, p. $262 ; 2016 \mathrm{~b}$, p. 148), the second stage (153 funerary structures) and the last stage (12 burials). In addition, the funerary ritual and the inventory reveal certain changes, by giving up certain features and the appearance of new characteristics, which can demonstrate a permanent contact with the areas of origin, unlike the Sarmatian burials in Lower Moesia, which continue to use the same code of display of the elite status even after it was abandoned in the North-Pontic areas (Oța, Sîrbu $2019 b$, in press). Especially in the absence of settlements, it is difficult to say at this time what happens to the Sarmatians from Wallachia in the few decades between the first two stages or after the middle of the $3^{\text {rd }}$ century, when the number of graves seems to decrease abruptly. The explanation is probably also related to the mobility of the population, which at one point chose to move to other areas (perhaps to the east of the Prut or, rather, in the North-Pontic area). A possible supplementation with newcomers of the Sarmatian communities that had already entered Wallachia at the end of the $1^{\text {st }}$ century $\mathrm{AD}$ or in the first decades of the following century is not supported by archaeological evidence, at least at the moment. I pointed out the existence of some graves, within the groups from Grădiştea (Oța, Sîrbu 2009, p. 194, 195), Păuleasca, Ciulnița, Ulmeni and Dorobanțu (Sîrbu et al. 2014, p. 126-128), which had certain archaic features of funerary ritual or chronological differences in terms of grave goods. The earlier dating of the above-mentioned burials based only on ritual similarities (more precisely the orientation of the graves and the position of the deceased individuals) with the Sarmatian graves from the first stage is however uncertain, especially if we consider the great variety of the features of the funerary ritual that characterize the early Sarmatian burials in Wallachia, a variety that is preserved, albeit to a lesser extent, in the second stage. We can talk about chronological differences only in two cases, from Măriuța and Ulmeni. The two Sarmatian burials from Măriuța are separated not only chronologically (G. 2 is dated to the end of the $1^{\text {st }}$ century $\mathrm{AD}$, while the dating of G. 2/2009 can be assumed during the second half of the $2^{\text {nd }}$ century AD - Sîrbu et al. 2014, p. 129), but also spatially (about $30 \mathrm{~m}$ ), without other Sarmatian burials between them (Lazăr et al. 2011, fig. 2). The situation in Ulmeni is complicated because of the destruction of sev- 

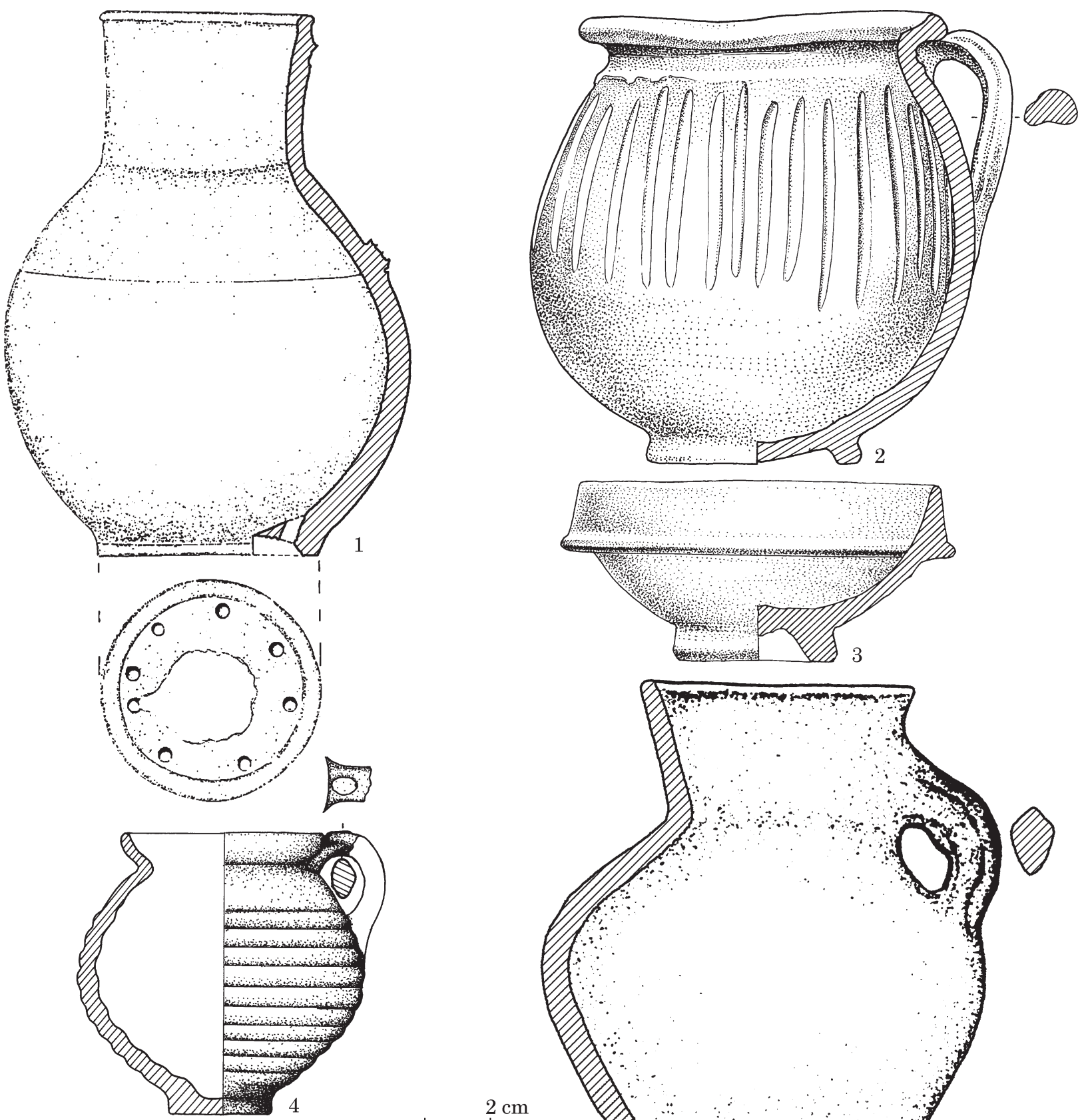

Fig. 1. Dacian, Roman and handmade pottery found in graves from the second stage of Sarmatian settlement in Wallachia: 1 - Bucu G. 7; 2, 3 - Brăila-Liceu; 4-BrăilaHipodrom G. 3; 5 - Ciulnița G. 18 (after: 1 - Rența 2000; 2—4 - Oța, Sîrbu 2009; 5 - Rența 2016)

eral inhumation burials (10-12), with pottery as inventory, on whose dating nothing can be said, due to the fact that the vessels were lost (Morintz, Ionescu 1968, p. 109, 110; Morintz, Ionescu 1970, p. 40). The hypothesis of a number of graves higher than the one currently known (five), of which some would have had a dating similar to that of G. 3 (more precisely during the second half of the $2^{\text {nd }}$ century AD - Sîrbu et al. 2014, p. 76-84, no. 41 , and p. 127,128 ) can no longer be verified, unfortunately. The data we have today for the group of graves and for the accidental discoveries from Ulmeni are limited to the capture of two
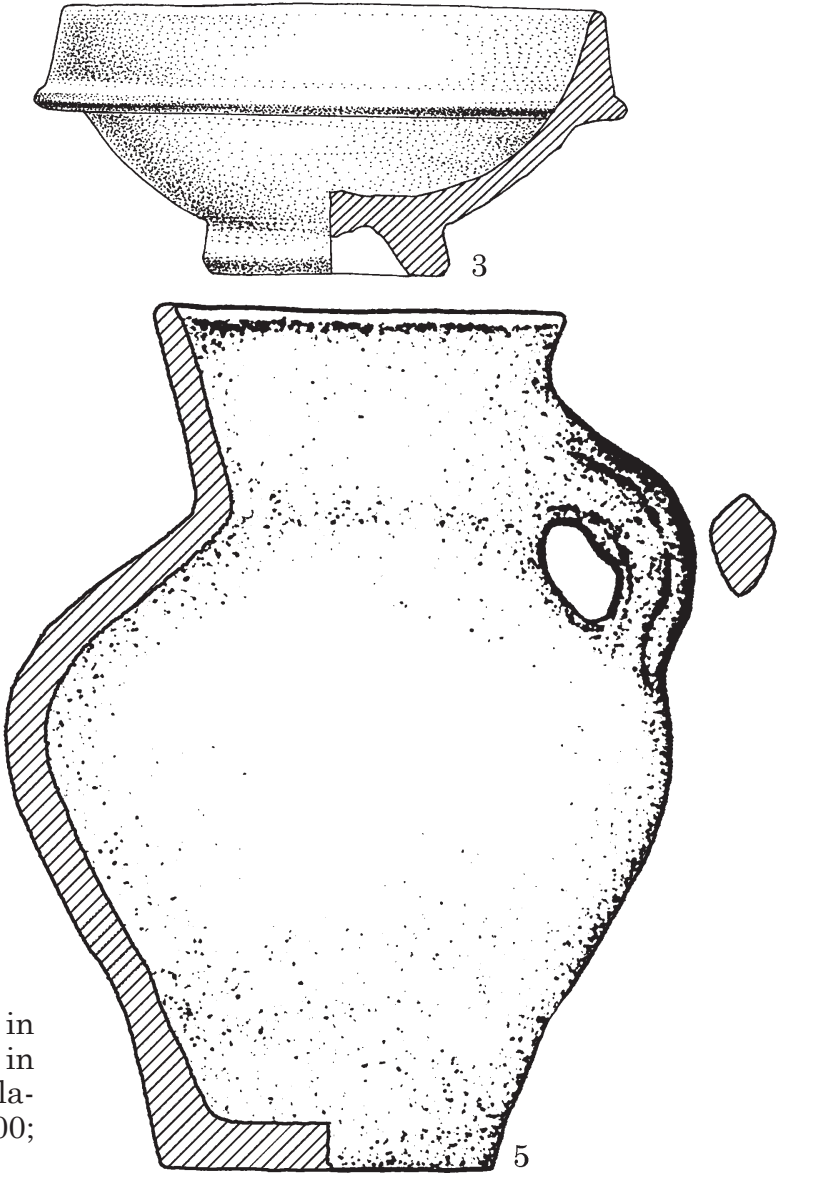

chronological moments (Sîrbu et al. 2014, p. 127, 128): an early one (the late $1^{\text {st }}$ century $\mathrm{AD}$ and the beginning of the following century - to which G. 1, 2 and 4, perhaps also G. 5 belong, and the bronze casserole and the glass unguentarium, too) and a later one (which can be dated during the second half of the $2^{\text {nd }}$ century $\mathrm{AD}$, if not later - G. 3 and a Roman mug discovered by accident). Given the fact that in Măriuța it is not possible to speak of a proper group, but rather of an accidental joining of the two graves (which becomes easier to understand due to the existence of a tell, therefore of an elevated terrain nearby 


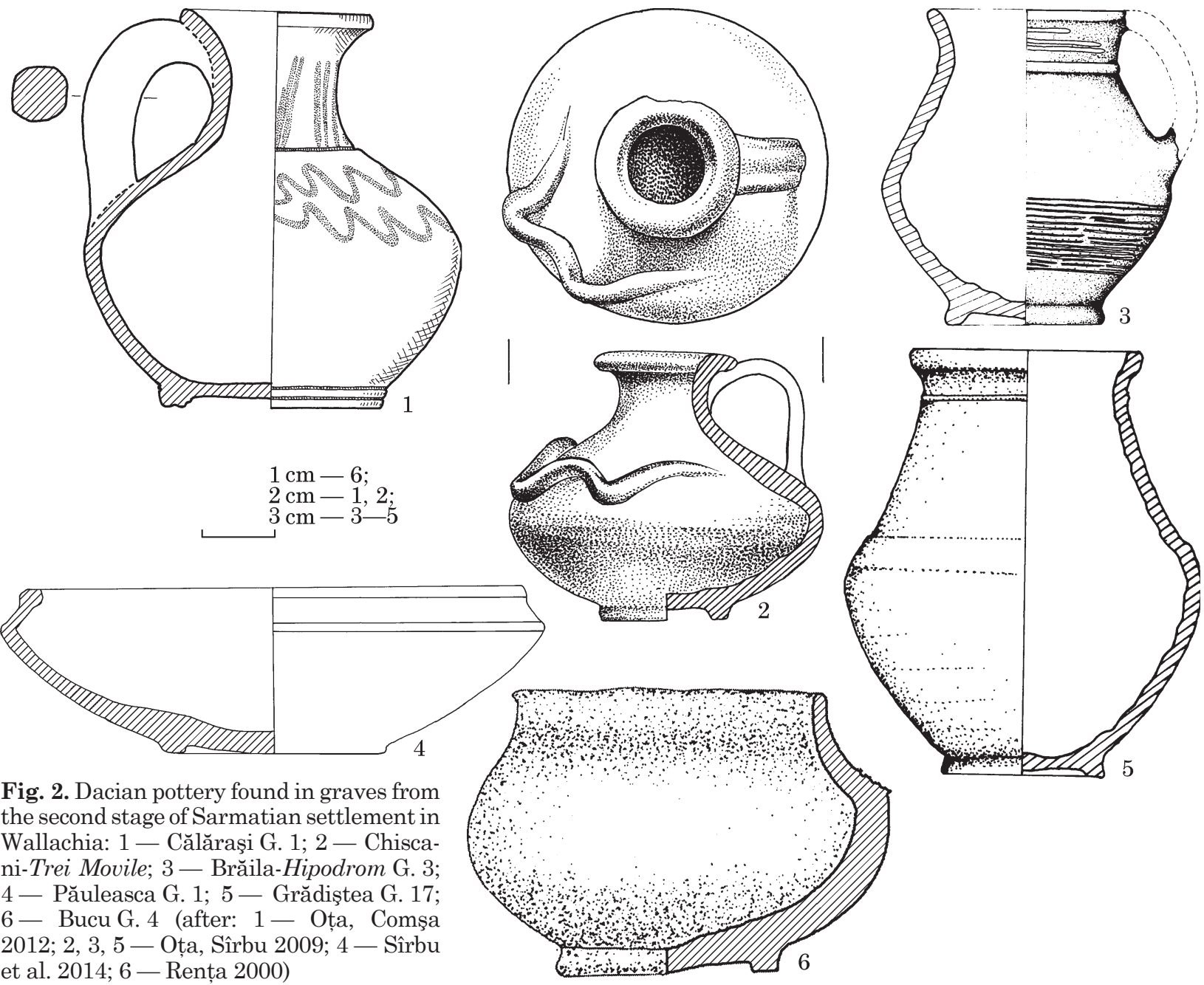

which could have served as a guiding mark Wendrich, Barnard 2008, p. 12), the situation in Ulmeni must, however, be analyzed with caution. The only grave that can be dated later belongs to a woman and its dating to the late $2^{\text {nd }}$ century $\mathrm{AD}$ is not very certain, which raises an additional doubt about a connection to the second stage of Sarmatian settlement in Wallachia, as the female mobility can have other explanations (exogamous marriage, for example - Rustoiu 2008, p. 28; Przybyła 2011, p. 237-241). This is the reason why I have included in this paper G. 2/2009 from Măriuța among the Sarmatian graves from the second stage of penetration of the Sarmatians in Wallachia, but I have excluded G. 3 from Ulmeni, at least for now.

Number and territorial distribution of graves. As I have already written, the number of burials that can be linked to the second stage of settlement of the Sarmatians in Wallachia currently amounts to 153 (fig. 9). It is not excluded that the nine funerary structures from PloieştiTriaj, if they could be indeed dated during the $3^{\text {rd }}$ century, could be also related to this moment (and then the number of graves would amount to 162), but, given that the funerary inventory is only listed without being illustrated at all and the mention of the coin issued by Emperor Elagabalus does not exist in the initial excavation report ${ }^{1}$, I chose to exclude them from my discussion for now.

The majority of the graves (130) were found in groups with variable numbers of funerary structures, ranging between two and 36. Again, an explanation is required. Although a total number of 36 Sarmatian graves in Târgşor and 16 in Oltenita-Renie is mentioned in the literature, the actual number of the graves that can be used for an analysis of the funerary ritual and inventory is only 32. A number of 18 graves from Târgşor are still unpublished, and from the 16 graves in Oltenita-Renie (which did not represent a proper cemetery, but groups of $4-6$ graves - Morintz, Ionescu 1968, p. 95, 96, 100, 101; Morintz, Ionescu 1970 , p. 38, 39) data is known about only nine of them. Therefore, in order not to introduce a very

1. The secondary graves in mound II researched in 1943 were dated to the $4^{\text {th }}$ century AD (Nestor 1944, p. 56; Vulpe 1987, p. 177; Comşa 1989, p. 181). The author who assigned these burials to the Sarmatians and who mentioned the presence in their inventory of a coin issued by Emperor Elagabalus in AD 219220 is Gh. Bichir (1971, p. 276; 1972, p. 139; 1977, p. 172,$193 ; 1985$, p. 1167). 
large margin of uncertainty in the analysis I will undertake, I decided to operate with the number of graves for which there is, in fact, information at the moment, and thus I excluded the 13 burials from Târgşor and the seven from Olteniț-Renie about which we have no data whatsoever. Leaving aside the two groups of graves above-mentioned, the number of graves from the remaining 18 groups is the following: 14 (Bucu), 10 (Largu and Grădiştea), eight (Oltenița-Iordoc), seven (Buzăusud), six (Ciulnița and Păuleasca), five (BrăilaHipodrom, Călăraşi G. 6-10 and Dorobanțu), four (Sultana), three (Jilava, Gălăți, OltenițCoada Lupului and Smeeni-Movila Mare) or two (Călăraşi G. 3-4, Cetatea Veche and Vlad Țepeş). 17 graves are isolated (Brăila-Liceu, BrăilaRadu Negru, Borduşelu, Bogdana, BucureştiDealul Piscului, Călăraşi G. 1, Căzăneşti G. 1, Chiscani-sat, Chiscani-Trei Movile, Dridu-sat, Măriuța G. 2/2009, Oltenița-Coada Malului, Pietroiu, Sudiți, Ulmu, Făurei near Ulmu, Mihail Kogălniceanu), to which can be also added the burials from Căscioarele, Dridu-tell, Luciu and Oltenița-Puțul de Cărămidă, because the other graves from Căscioarele and Luciu were completely destroyed, and G. 1 from Dridu-tell and G. 2 from Oltenița-Puțul de Cărămidă are chronologically uncertain. Due to their accidental discovery and the fact that they are unpublished, it is not known if G. 2 from Călăraşi ${ }^{1}$ and the only grave about whose inventory there is a mention from Chirnogi are isolated or were part of groups of graves.

The aspect that draws attention most of all by comparison with the first stage of arrival of the Sarmatians in Wallachia is that the total number of funerary structures that can be attributed to the second stage has almost tripled, which seems to indicate a higher number of Sarmatian communities that arrived now in Wallachia. Two aspects are to be emphasized regarding the territorial distribution of the graves. The first, immediately visible on the map (fig. 9), is the extension of the regions with Sarmatian discoveries, although, on the whole, they do not uniformly cover the entire territory of Wallachia. To the previously known areas (northeast, east and south of Wallachia), the center and north of Wallachia are added. The second aspect regards the change of the center of gravity of the Sarmatian discoveries, now concentrated in the southern and eastern part of Wallachia (92 graves), less in the northeastern region (41 graves) or the central-northern region of Wallachia (40 burials). Regarded in terms of geographical area, the evolution of the Sarmatian discoveries shows that the real explosion takes place in southern and eastern Wallachia (if only 8-10 discoveries, most of them isolated - Oța, Sîrbu 2016a, p. 262; 2016b, p. 149 - are known

1. For the bibliography of the graves, see the catalogue, at the end of the paper. in the first stage, in the second stage there are 13 groups, totalizing 76 graves and 14 isolated discoveries, added by two more graves about which it cannot be said whether they were isolated or not). The northeast of Wallachia has not so much an increase of the number of discoveries - compared to the 41 or 43 graves that could be dated in the first stage (Oța, Sîrbu 2016a, p. 262; 2016b, p. 149), the number remained the same in the second stage (41), of which six isolated discoveries and 35 graves concentrated in five groups, as a change of the territorial distribution, by extending to the Buzău Plain and the Subcarpathian region, along the courses of the Buzău and Călmăți rivers. Although numerically comparable to northeastern Wallachia (40 graves), however, the central and northern regions of Wallachia remain exceptions in terms of the Sarmatian discoveries, concentrated in only three sites.

The grave layout, the age and sex of the buried individuals. Unlike the Sarmatian graves dated in the last decade of the $1^{\text {st }}$ century $\mathrm{AD}$ and the first decades of the following century (Oța, Sîrbu 2016a, p. 265; 2016b, p. 149), which were buried especially in elevated terrain (the socalled tells), in the late $2^{\text {nd }}$ century $\mathrm{AD}$ and the first half of the following century, most graves (122) are flat. There are 29 exceptions, of which 13 are tumular burials (Jilava, Ciulnița, SmeeniMovila Mare, Făurei), 10 in sand dunes (Largu) and six in tells (Căzăneşti, Dridu-tell, Sudiți and Gălătui). As regards the layout of the graves, it should be noted the disappearance in the second stage of the individual tumular graves. Except for the secondary burial from Făurei (individual burial), all the other secondary graves buried in already raised mounds are grouped (three burials in Jilava, six in Ciulnița distributed into two tumuli, three at Smeeni). Except for the three graves from Gălătui, the rest of the tell burials are singular (Căzăneşti, Dridu-tell and Sudiți). The disappearance of the tumuli (either purposely raised as in Vităneşti - Leahu, Trohani 1979, p. 127, 128, 133; Sîrbu et al. 2014, p. 85-89, or already existent as in Mohreanu and Roşiori Oța, Sîrbu 2009, p. 129, 132, 133) is noticed only in the case of the individual elite burials, so probably the tumuli lose their value as status symbol (Mordvintseva 2016, p. 393) in the second stage and remain simple burial places, perhaps easier to located in the surrounding landscape.

Unfortunately, the orientation of a high number of graves (45) is unknown. Unlike the previous period (Oța, Sîrbu 2016a, p. 265; 2016b, p. 149), in the second stage there is a uniformity of the orientation of the graves in the $\mathrm{N}-\mathrm{S}$ direction (83), with the NW-SE variations (10) and NE-SW (two), which means an overwhelming percentage of $88.78 \%$ of the number of graves for which the orientation is known. The exceptions are only 11 (possibly 13, if G. 3 and G. 7 from Oltenița-Renie would not be $\mathrm{N}-\mathrm{S}$ oriented), most of them (nine) 

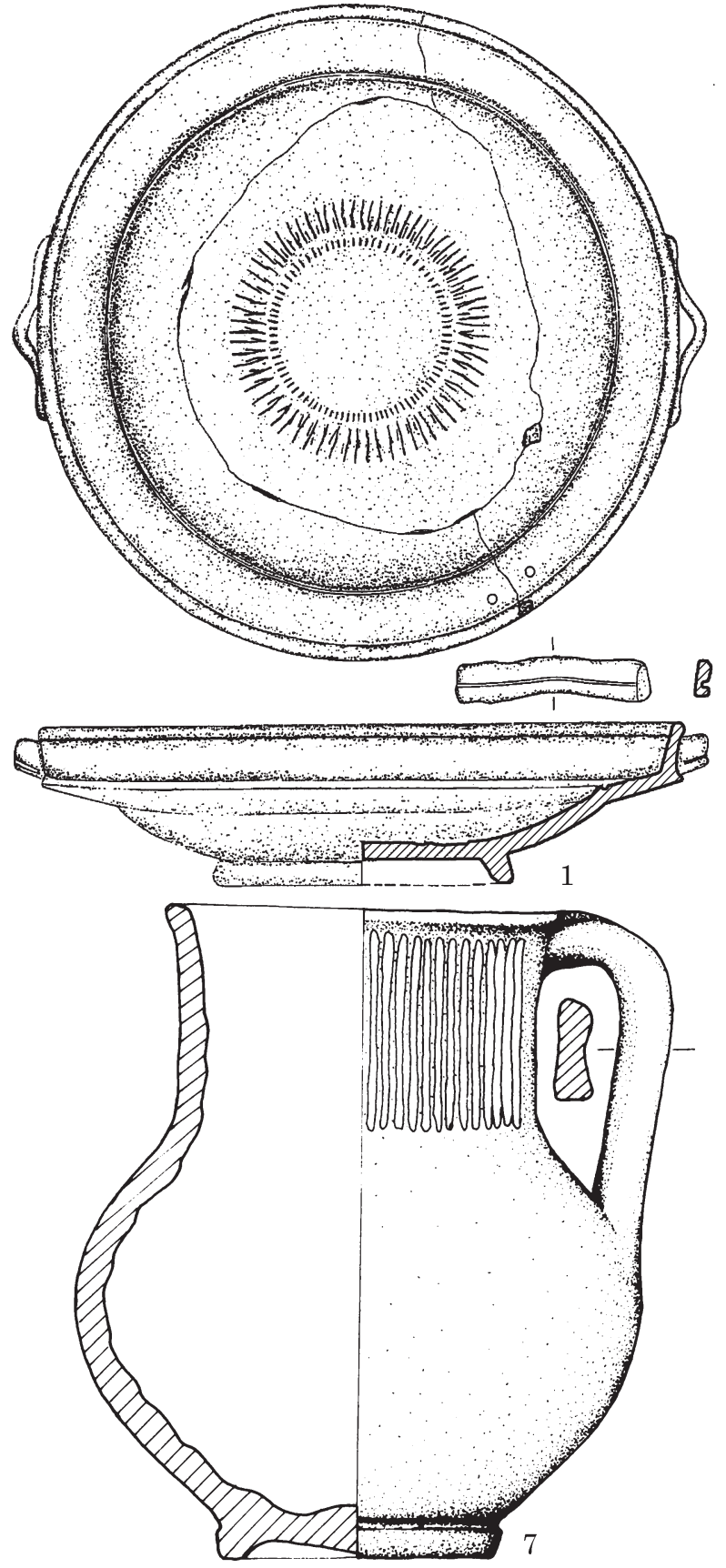

in the E-W direction (all five graves from BrăilaHipodrom, G. 2 and G. 3 from Smeeni-Movila Mare, G. 10 in T. III from Ciulnița ${ }^{1}$ and the burial from Chiscani-Trei Movile). Prevalent in the first stage, the orientation in the $\mathrm{W}-\mathrm{E}$ direction is registered in the second stage only exceptionally (G. 10 from Smeeni), while the $\mathrm{S}-\mathrm{N}$ orientation remains singular (G. 23 from Păuleasca).

1. Initially published as being oriented in the $\mathrm{W}-\mathrm{E}$ direction (CCA 1994, p. 23) and later, in a monograph, E-W (Renta 2016, p. 96, 97). It is obvious that somewhere there is a typo, but I decided however to take into consideration the information published in the monograph, given the similarity with the five graves with the same orientation from Brăila-Hipodrom.

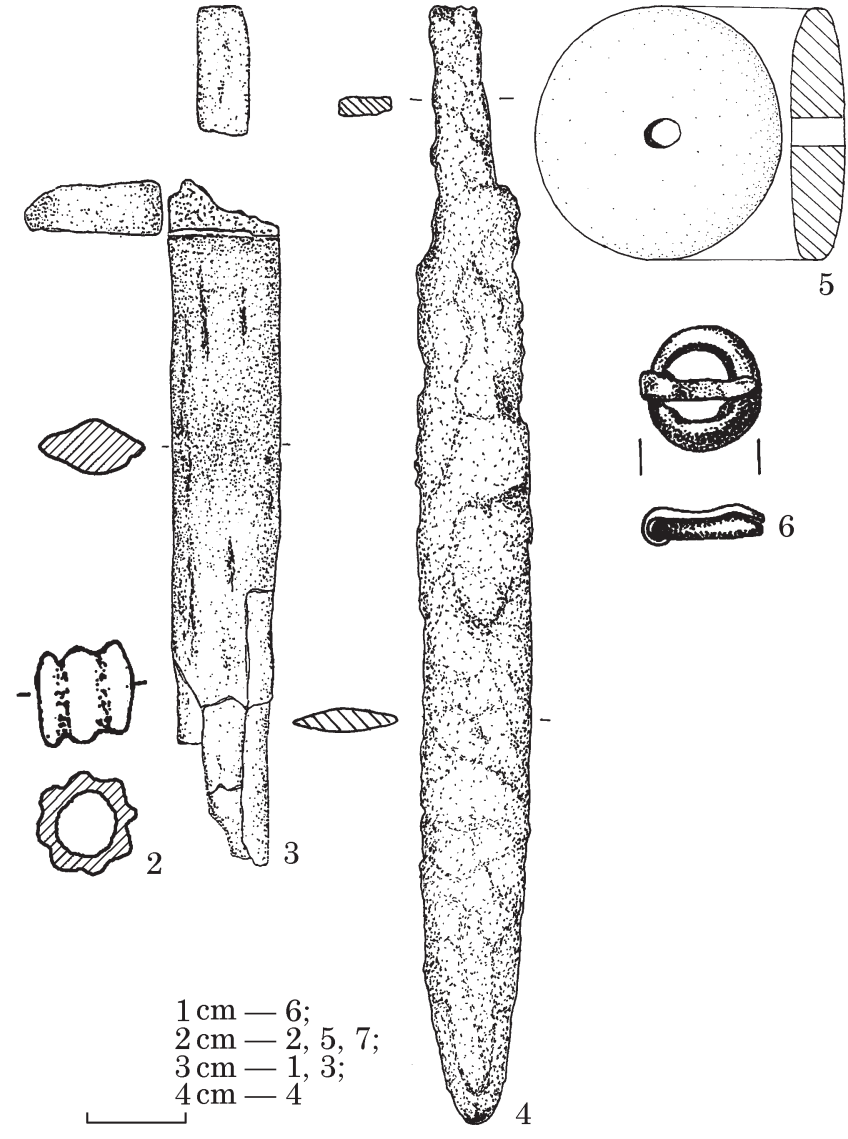

Fig. 3. Sarmatian graves with weapons: $1-3-$ Bucu G. 10; 4-7 - Brăila-Hipodrom G. 2 (after: 13 - Rența 2000; 4-7 - Oța, Sîrbu 2009)

Although with an unexpectedly high number of cases (65) in which it is not known, some observations can also be made in connection with the position in which the deceased individuals were buried. Again, for the graves from the second stage of Sarmatian settlement in Wallachia, a tendency towards uniformity can be observed, more precisely the prevalence of the supine position, with legs extended and arms extended along the body (68 cases, which means a percentage of $77.27 \%$ ). There are 20 exceptions, but in most cases these are positions registered in one single case: with the right hand on the pelvis and the legs extended (Târgşor G. 208), with the right hand on the pelvis and the legs slightly bent (Bucureşti-Dealul Piscului), with arms extended and the right leg bent (Ciulnita G. 18), with the right hand on the pelvis and the right leg bent (Buzău-sud G. 6), with the arms extended and the left leg bent (Grădiştea G. 11), body laid out in dorsal position, with arms extended and left leg slightly bent (Gălățui G. 3), with left arm extended along the body, right arm bent, palm towards the head and disturbed position of the legs (Măriuța G. 2/2009), lying on the left, with legs extended, left arm bent with the palm under the chin and right arm above the head (Grădiştea G. 17), with the thorax lying on the left, the skull turned to the right, arms extended and both legs bent (Târgşor G. 200 - 
fig. 8: 9). More common are the crouched position (five cases - Păuleasca G. 2, 3, 57 - fig. 8: 8, Oltenița-Coada Malului and Târgşor G. 415), the supine position with the palms on the pelvis (four cases - Bucu G. 6, Buzău-sud G. 6, Dridu-tell, Târgşor G. 219) and the supine position with the left hand on the pelvis (Grădiştea G. 9, Târgşor G. 221). A review of the orientations and the positions of the deceased in groups with more than two burials creates space for a few observations. Regarding the orientations, there are several groups, some even with a high number of graves, where the $\mathrm{N}-\mathrm{S}$ orientation was chosen exclusively (the 10 burials from Grădiştea, the seven from Buzău-sud, the three graves from Gălățui and Oltenita-Coada Lupului) or E-W (the five graves from Brăila-Hipodrom). The groups that certainly have deceased individuals with a different orientation than the prevailing one are Oltenița-Renie (one or two deceased oriented $\mathrm{E}-\mathrm{W}$ ), Ciulnita (a deceased oriented E-W), Smeeni-Movila Mare (a deceased oriented $\mathrm{W}-\mathrm{E}$ ). The uniformity is less pronounced in the case of the positions of the deceased individuals, where only the five graves from Brăila-Hipodrom have the same position (body laid out in supine position with legs extended and arms extended along the body) and the three burials from Smeeni-Movila Mare (same position). Otherwise, if only the known positions are taken into account, various positions are registered even in the homogeneous groups in terms of orientation: Grădiştea (seven supine positions with arms and legs extended and three exceptions), Buzău-sud (four supine positions with arms and legs extended and two exceptions), Gălăți (two supine positions with arms and legs extended and one exception). Unfortunately, as regards the rest of the groups, the large number of graves for which the position of the deceased is unknown does not allow, at least for the time being, certain conclusions about the prevalence of a certain position. The reason for choosing an orientation or a position different from the majority cannot be deciphered, at least for the moment. However, it does not seem to be related to the age of the deceased individuals (as the only children are those from G. 23 and G. 2, 3 from Păuleasca, a group that is characterized, however, by the large number of burials of children, more precisely four - Sîrbu et al. 2014, p. 126) nor with differences in social status, at least judging by the example from Brăila-Hipodrom, where all five adults were buried with the same orientation and position, whether or not they had inventory. In Târgşor, three of the graves with position different from the supine position with arms and legs extended had no inventory (G. 219, 221 and 415), but other three graves without inventory were not characterized by another orientation or position (G. 220, 227, 274), and G. 200 and 208, with other positions than the majority, had grave goods that did not differ from that of the rest of the burials.
Also in connection with the treatment of the deceased, three particular cases, all from Târgşor, should be mentioned: the interment in a pit shorter than the body (G. 255, which resulted in the movement of the jaws), the diagonal deposition of the deceased in the pit (G. 220) and the deceased covered with four stone blocks (G. 118). Another particular case concerns G. 1 from Ciulnița, where a man and a woman were buried together (fig. 6: 1), both with the same orientation $(\mathrm{N}-\mathrm{S}$ ) and position (lying on their backs with their arms extended along their bodies and their legs extended, only with the right forearm of the woman slightly overlapping that of the man), reason for which I considered, in the statistics of orientations and positions, that it is a single case and not two different burials.

Of the 92 cases where the age of the deceased individuals could be determined, most are adults - 62 graves, with 63 individuals (Gălătui G. 2, 3, Măriuța G. 2/2009, Oltenița-Renie G. 6, 9, Bucu G. 6, 8-10, 14, Ciulnița G. 3, both deceased individuals in G. 1, 18, Păuleasca G. 57, Călăraşi G. 1, one grave from Vlad Țepeş, Grădiştea G. 1, 4, 5, 9, 13, 17, 18, Brăila-Hipodrom G. 1-5, BrăilaLiceu, Brăila-Radu Negru, Buzău-sud G. 1-6, Cetatea Veche G. 1, Chiscani-sat, ChiscaniTrei Movile, Largu G. 4-8, Smeeni G. 2-3, 10, Târgşor G. 148, 184, 196, 198, 200, 205, 206, 208, $219,221,228,253,255,267,274)$. The 27 burials of children are: Oltenița-Iordoc G. 4, OltenițaRenie G. 2, 8, Bucu G. 1-5, 7, 11-13, Ciulnița G. 2, 4, Păuleasca G. 23, 26, 2, 3, Grădiştea G. 12, 19, Jilava G. 1, 2, Largu G. 2, 3, Târgşor G. 220, $227,261)$. In three graves were buried adolescent females (Dridu-tell G. 2, Grădiştea G. 11, Largu G. 1).

Even if the large number of undetermined cases (93) is likely to call into question any conclusion, it is perhaps worth mentioning that, out of 60 individuals whose sex can be known (by anthropological analysis or the judgment of the archaeologist: Călăraşi G. 1, 7, 9, Căscioarele, Gălății G. 2, 3, Măriuța G. 2/2009, Dridu-tell G. 2, the deceased female in G. 1 from Ciulnița, Buzău-sud G. 3, 6, Cetatea Veche G. 1, Smeeni G. 2, Târgşor G. 184, 198, 200) or assumed (based on the funerary inventory: Borduşelu, Călăraşi G. 3, 6, Pietroiu, Olteniț-Renie G. 1, 7, Dridu-sat G. 1, Bucu G. 6, 8, Mihail Kogălniceanu, Gălătui G. 4, Oltenița-Iordoc G. 2, 3, Brăila-Radu Negru, Chiscani-sat, Grădiştea G. 9, 11, Largu G. 1, 7, 9, Luciu, Târgşor G. 411, possibly also BucureştiDealul Piscului), 39 are women. We can talk about «male» funerals in the case of G. 1 from Ciulnița (one deceased out of two), G. 1 from Căzăneşti, G. 6 from Oltenița-Iordoc, G. 3 from OltenițaRenie, G. 10 from Bucu, G. 2 from Brăila-Hipodrom, G. 1, 2 and 4, 5 from Buzău-sud, G. 1 and 4 from Grădiştea, G. 4 and 6 from Largu, G. 3 and 10 from Smeeni-Movila Mare, G. 148, 196, 205, 208, 255 from Târgşor. 

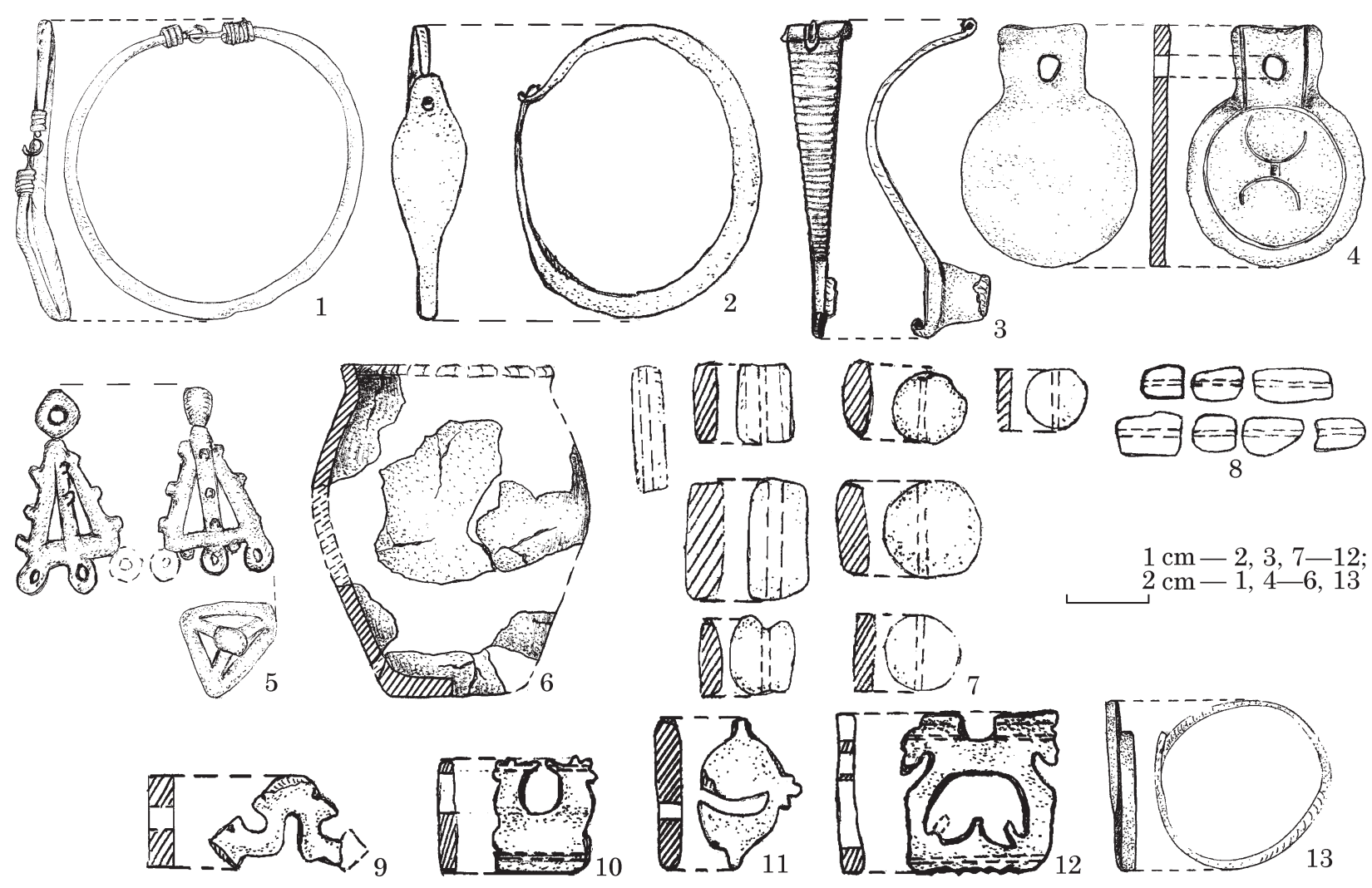

Fig. 4. Sarmatian grave from southern Wallachia, Călăraşi G. 7 (after Sîrbu et al. 2014)

About the age ratio of the deceased individuals from the different groups of Sarmatian burials I wrote on another occasion (Oța 2018, p. 44-46, table 1). The groups where adult burials prevail are: Grădiştea ( 7 out of 10 ), Largu (5 out of 10 , but the adolescent female from G. 1 can also be added here, because strictly in terms of funerals there is no difference between the burials of women and those belonging to adolescent females Oța, Sîrbu, Matei 2013, p. 334, 335), Târgşor (15 out of 23) and Ciulnita (4 adults in 3 graves). The majority of the deceased in the groups from Bucu (9 out of 14), Păuleasca (4 out of 6 ) and Jilava (2 out of 3) are children. The groups from BrăilaHipodrom (5 burials), Smeeni-Movila Mare (3), Gălățui (3, all women) and possibly Buzău-sud (6 certain burials out of 7) are made up exclusively of adult graves.

The intentional cranial deformation could be observed in 13 cases: Bucu G. 3, Călăraşi G. 1 and 9, Cetatea Veche G. 1, Dridu-tell G. 2, Largu G. 6, Mihail Kogălniceanu, Oltenița-Puțul de Cărămidă G. 1, Târgşor G. 184, 196, 200, 205, 267 (Oța 2015, p. 119-134).

Grave goods. If from the total number of graves that can be linked with the second stage of Sarmatian settlement in Wallachia are subtracted the 18 graves that had no inventory (which means a percentage of $11.76 \%$ ) and the 10 graves about whose inventory we have no data, 125 burials remain valid for an analysis of the grave goods.

The most common category of grave goods is represented by the ceramic vessels, deposited in at least 83 funerary structures (the expression "at least» is due to the fact that the inventory of the three burials from Oltenita-Coada Lupului is published in block, so it is difficult to know exactly in how many graves pottery was found). Regarding the minimum 42 graves in which pottery was not deposited, it can be seen that this custom is not attested at all in the group of three graves from Gălății and is rarely found (only in three graves out of seven) in Largu. A fairly large number of graves in which the funerary inventory did not contain ceramic vessels is also attested in Târgşor (nine burials out of the 23 about which we have information, therefore a percentage of $39.13 \%$ ). In the case of the double burial in G. 1 from Ciulnita, the woman had a vessel as funerary inventory, while the man did not.

A single vessel was deposited in most of the graves (55). The inventory of 18 graves included two vessels, three vessels were deposited in three cases and in G. 7 from Oltenița-Renie were discovered seven vessels. The number of the ceramic vessels cannot be known in eight cases, either because of the publication deficiencies, or because the funerary inventory was partially or totally destroyed as a result of their accidental discovery.

Unlike the graves dated to the late $1^{\text {st }}$ century $\mathrm{AD}$ and in the first decades of the following century (Oța, Sîrbu 2016a, p. 269—272; 2016b, p. 151153), in most burials dated to the late $2^{\text {nd }}$ century $\mathrm{AD}$ and in the first half of the $3^{\text {rd }}$ century, Dacian wheel-made pottery was deposited (certainly in 41 tombs, maybe 42 if the vessel in G. 1 from 
Oltenița-Iordoc would also be Dacian). An explanation is required regarding the fact that I have included the grave from Brăila-Liceu and G. 10 from Smeeni among the graves with two vessels. Although the cup from Brăila-Liceu covered the pot (fig. 1: 2, 3), the functionality of the vessels (Suceveanu 2000, p. 60, 99) led me to think that, in this case, we are dealing with two different vessels, which were placed on top of each other only because of the particular circumstance of the burial. Normally, a jar covered with a special lid should be regarded as a single recipient, but the fact that the jar in G. 10 from Smeeni was deposited near the head while the lid was deposited at the feet could indicate an intentional separation of the two ceramic vessels.

The typology of the vessels (about the typology of the Dacian vessels found in Sarmatian graves from Wallachia, see Oța, Sîrbu 2009, p. 152-155; 2012, p. 125-163; Sîrbu et al. 2014, p. 104-106) is much more varied compared to the Dacian pottery previously deposited: mugs (28 graves - Brăila-Hipodrom G. 1-3- fig. 2: 3;

3: 7, Bucureşti-Dealul Piscului, Jilava G. 1 and 3, Buzău-sud G. 1, 2, 5, 6, Călăraşi G. 1, 4, 10, Căscioarele, Cetatea Veche G. 1, Chiscani-sat fig. 5: 3, Dorobanțu G. 5, Grădiştea G. 17, Largu G. $4,6,7$, one grave from Oltenita-Coada Lupului, Oltenița-Iordoc G. 3, Oltenița-Renie G. 3, 7, 9, Smeeni G. 2, 3), bowls (seven - Buzău-sud G. 7, Călăraşi G. 8, Cetatea Veche G. 1, Luciu - fig. 7: 1, Oltenița-Renie G. 7, Păuleasca G. 1 - fig. 2: 4, perhaps Oltenița-Iordoc G. 1), jugs (five recipients - Bucu G. 2, Călăraşi G. 1 - fig. 2: 1, Chiscani-Trei Movile - fig. 2: 2, Oltenița-Renie G. 4, Târgşor G. 253), biconical vessels (Brăila-Radu Negru, Grădiştea G. 9 - fig. 5: 10 and 17 - fig. 2: 5), pot (Târgşor G. 196), cut mug (Bucu G. 4 - fig. 2: 6 ). The handmade pottery (about the typology of the handmade pottery see Ota 2014-2015, p. 99-101; Oța, Sîrbu 2009, p. 150-152; Sîrbu et al. 2014 , p. 102,103$)$ from the 36 graves consists mainly of jars (29 cases - Brăila-Hipodrom G. 1, Bucu G. 1, 6, 12, Jilava G. 1, 2, Borduşelu, Buzău-sud G. 4, Călăraşi G. 6, 7 - fig. 4: 6, Cetatea Veche G. 2, Chiscani-sat - fig. 5: 1, Ciulnița G. 2-4, Dorobanțu G. 1, Grădiştea G. 5, 9 - fig. 5: 7; 11, 17, Largu G. 3, 7, Oltenița-Renie G. 2, 7, Smeeni G. 10, Târgşor G. 184 - fig. 7: 9; G. 198 - fig. 8: 2, 3; G. 261, 267), less from mugs (Bucu G. 13 and Ciulnița G. 18 - fig. 1: 5) or bowls (Sultana G. 3).

The typology of the ceramic vessels (Oța, Sîrbu 2009, p. 174; Sîrbu et al. 2014, p. 106, 107) imported from the Roman provinces found in 12 graves indicates a prevalent deposit of mugs (eight cases - Brăila-Hipodrom G. 3 - fig. 1: 4, perhaps also G. 2, Bucu G. 14, Buzău-sud G. 2, Grădiştea G. 19, Luciu - fig. 7: 2, Măriuța G. 2/2009 and Sudiți). Much less common are the pots (BrăilaLiceu - fig. 1: 2 and Jilava G. 2), the jugs (Bucu G. 7, reused - fig. 1: 1, and Luciu - fig. 7: 3), the cup (Brăila-Liceu - fig. 1: 3), and the bowl (Bucu G. 10, repaired - fig. 3: 1).

An attempt to correlate the type and number of ceramic vessels discovered inside a grave indicates that, where a single vessel was deposited, it was mainly handmade pottery (24 funerary structures) or Dacian wheel-made pottery (22 burials), while Roman vessels are much less common (only six cases). Due to its fragmentary state, we cannot know the type of the handmade vessel found in G. 13 from Grădiştea, G. 4 from Oltenița-Iordoc and G. 1 from Oltenița-Renie, however this observation is not likely to change the conclusion about the prevalence of the handmade jars in the case of depositing one vessel in the funerary structure (18 graves - the jars in G. 1 and 6 from Bucu, Buzău-sud G. 4, Călăraşi G. 6, 7, Cetatea Veche G. 2, Ciulnița G. 3, 4, Dorobanțu G. 1, Grădiştea G. 11, possibly also 5, Largu G. 3, Olteniț-Renie G. 2, Târgşor G. 184, 261, 267 and the jars with lids from Borduşelu and G. 2 from Ciulnita). The handmade mug was the only recipient in the inventory of G. 13 from Bucu and G. 18 from Ciulnița, and in G. 3 from Sultana a bowl was found, this one also handmade. The only vessel that falls in the category of Dacian wheel-made pottery that was deposited in the 22 funerary structures with a single ceramic recipient was notably the mug (14 cases - BucureştiDealul Piscului, Jilava G. 3, Buzău-sud G. 1, 5, Călăraşi G. 4, 10, Căscioarele, Grădiştea G. 4, Largu G. 6, Oltenița-Iordoc G. 3, Oltenița-Renie G. 3, 9, Smeeni G. 2, 3), less often jug (Bucu G. 2, Oltenița-Renie G. 4, Târgşor G. 253) or bowl (Buzău-sud G. 7, Păuleasca G. 1, and OltenițaIordoc G. 1, if it is indeed a Dacian vessel) and quite exceptionally biconical vessel (Brăila-Radu Negru) or cut mug (Bucu G. 4). As regards the Roman pottery, in four graves was deposited a mug (Bucu G. 14, Măriuța G. 2/2009, Sudiți, Grădiştea G. 19), and in other two cases a jug (Bucu G. 7) and a bowl (Bucu G. 10).

The combinations between the types of the two vessels in the 18 graves in which two ceramic vessels were deposited are characterized by a great variety. Only Dacian wheel-made vessels were discovered in G. 6 from Buzău-sud and G. 5 from Dorobanțu (both mugs), G. 1 from Călăraşi (mug and jug), G. 1 from Cetatea Veche, possibly also G. 8 from Călăraşi (mug and bowl). The associations between a handmade vessel and a Dacian wheel-made vessel are notably jar + mug (BrăilaHipodrom G. 1, Jilava G. 1, Chiscani-sat - fig. 5, Largu G. 7) or undetermined type of vessel + pot (Târgşor G. 196). In three cases, handmade vessels were observed (two jars in G. 12 from Bucu and G. 198 from Târgşor - fig. 8, jar + lid in G. 10 from Smeeni), and in the same number of graves a Dacian wheel-made recipient is combined with a Roman vessel (without exception Dacian mug + Roman mug in G. 2 and 3 from Brăila-Hipodrom and G. 2 from Buzău-sud). The associations be- 

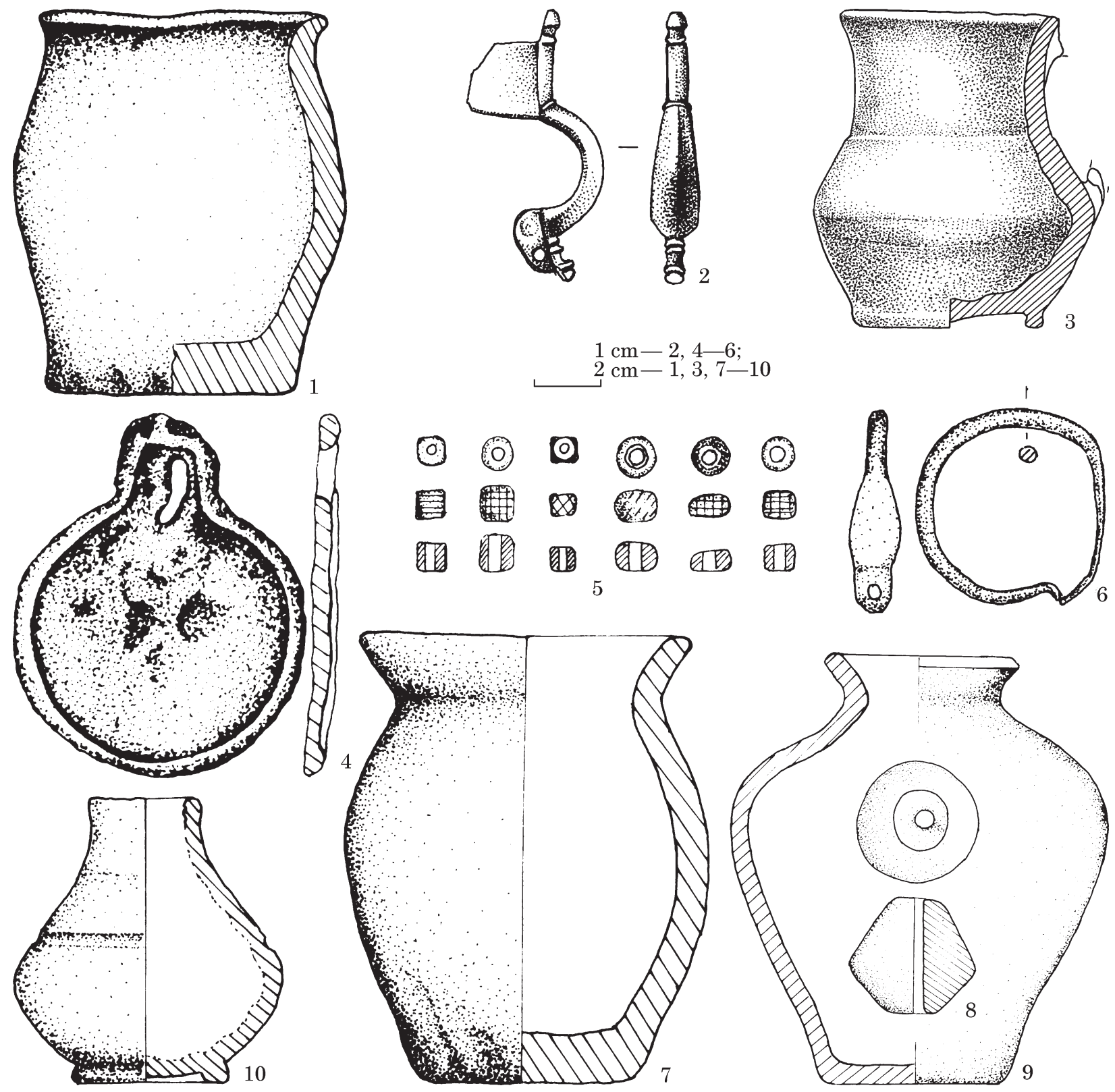

Fig. 5. Sarmatian graves from northeastern Wallachia: 1-6 - Chiscani-sat; 7-10 - Grădiştea G. 9 (after Oța, Sîrbu 2009)

tween two Roman vessels (Brăila-Liceu — fig. 1: 2, 3) and a handmade vessel and a Roman one (Jilava G. 2) are singular cases. Each of the three graves with three vessels revealed a different combination of types of containers: two handmade jars + Dacian biconical vessel (Grădiştea G. 9 - fig. 5), handmade jar + Dacian wheel-made mug + Dacian biconical vessel (Grădiştea G. 17), Roman wheel-made jug + Roman mug + Dacian wheelmade bowl (Luciu - fig. 7). Two of the seven vessels in G. 7 from Oltenița-Renie are not described, but the other five are either handmade (both jars), or wheel-made (two mugs and one bowl, all Dacian pottery). In order to conclude, other two observations should be noted: exclusively handmade pottery was discovered in the six graves from Ciulnița, Roman pottery seems to be absent in the case of the eight graves with inventory from Călăraşi, the 10 burials from Largu and the eight graves with inventory from Olteniț-Renie. Although the Roman pottery is absent in the 14 burials about which we are able to gather information from Târgşor, however, the mention of three Roman vessels (bowl, pot and mug - Niculescu 2003, p. 195) in the unpublished graves excludes this necropolis from among those in which Roman pottery was not registered as grave goods.

Regardless of the origin of the ceramic vessels, their presence in the graves seems to emphasize, just like in the first stage, the functionality of the recipient and not a possible increase in its value, dictated by the way it was achieved (Theuws 2009 , p. 292). The positions in which the vessels were found remain the same as in the previous period - near the head or the feet, added by the deposit in the shoulder area (Ciulnița G. 3 and 

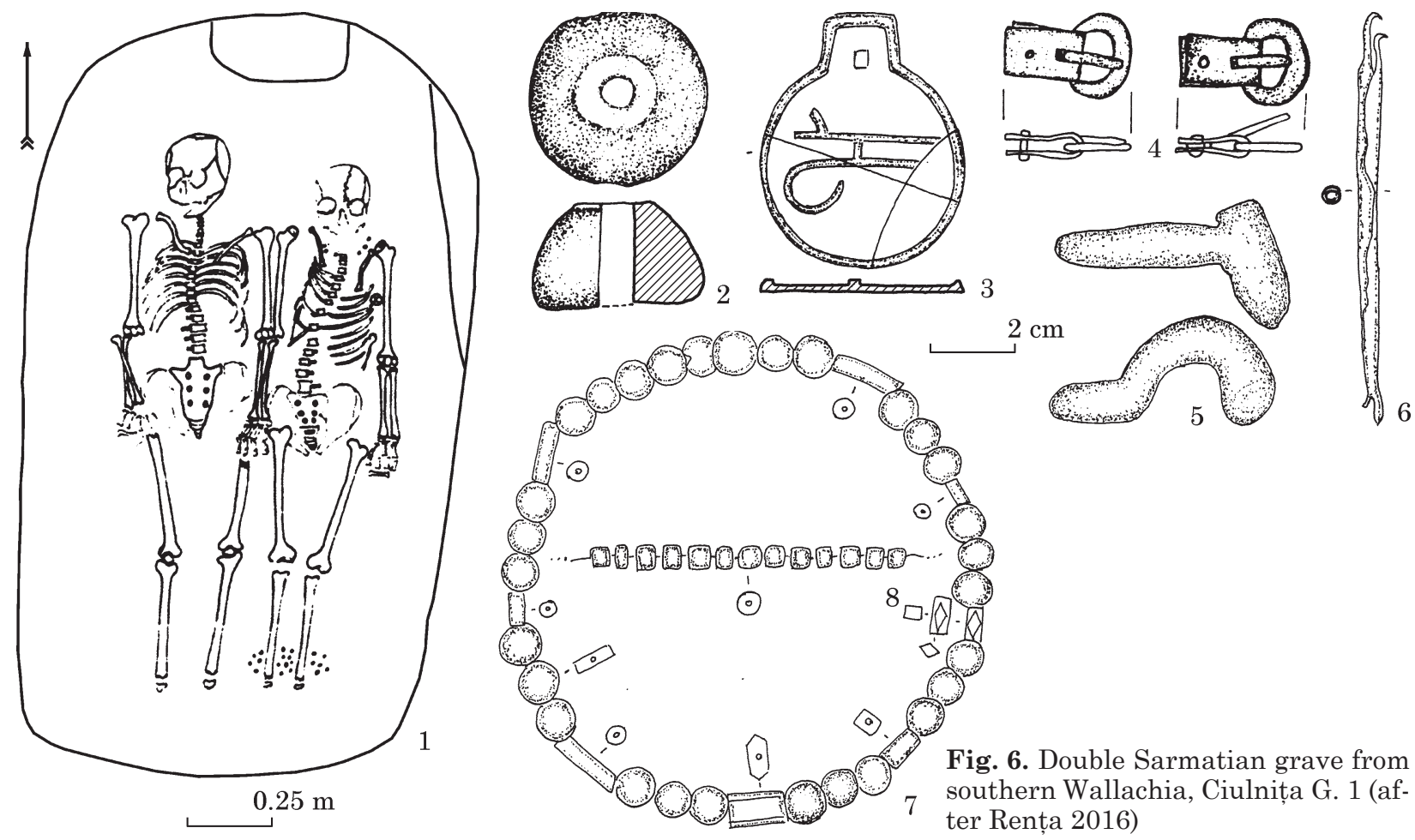

10), the thigh area (the handmade vessels from Călăraşi G. 7, Oltenița-Renie G. 1 and Târgşor G. 198) or the area of the knees (the Dacian mugs in G. 1 and 2 from Buzău-sud near the right knee; the handmade jar in G. 2 from Ciulnița over the knees; the Dacian mug in G. 2 from Smeeni over the tibiae). An additional argument in favour of the emphasis placed on the functionality of the vessel is the grouped deposit inside the graves of recipients of different tradition: handmade jar and Dacian wheel-made mug, both deposited near the head in G. 1 from Brăila-Hipodrom, Dacian mug and Roman mug in the same position in G. 2 from Brăila-Hipodrom, the handmade jar and the Dacian wheel-made mug deposited near the feet in the funerary structure from Chiscanisat, handmade jar and Dacian pot in the same position in G. 196 from Târgşor, two handmade jars and a Dacian biconical vessel deposited near the feet in G. 9 from Grădiştea. When speaking of different positions of the pottery inside the grave, one can notice a tendency to place near the head especially the handmade vessels and near the feet Dacian or Roman vessels (Jilava G. 1, 2, Grădiştea G. 17, Oltenița-Renie G. 1), although there are exceptions (apart from the already mentioned G. 10 from Smeeni where the jar was found near the head and the lid in the area of the feet, we can mention G. 198 from Târgşor where the handmade jars were deposited near the head or in the thigh area, and G. 7 from Largu where the handmade jar was found near the feet and the Dacian mug in the area of the knees).

The adornments are observed in a relatively small number of graves - 36, but it should be noted from the beginning that this number may be due to the quite numerous cases in which the position of the beads is unknown, therefore some doubts raise whether or not they were adornments in the proper sense of the term (Oța, Sîrbu 2016a, p. 272; 2016b, p. 153; Sîrbu et al. 2014, p. 108). The adornments found in the graves of the second stage of Sarmatian settlement in Wallachia are: beads (22 graves - Brăila-Liceu, Bucu G. 8, Călăraşi G. 7 - fig. 4: 7, 8, Căscioarele, Chirnogi, Chiscani-sat, Ciulnița G. 1B - fig. 6: 7, 8, G. 18, Dridu-tell G. 2, Grădiştea G. 11, Largu G. 1, 2, 7, Măriuța G. 2/2009, Oltenița-Renie G. 1, 8, Târgşor G. 184 - fig. 7: 13, 14, G. 198 - fig. 8: 5, G. 206 , 267, probably also G. 3 from Gălățui, and G. 5 from Largu); earrings (22 graves for sure, perhaps 23 if the item from Largu G. 5 is an earring and not a pendant); pendants (five graves: Călăraşi G. 7 - fig. 4: 5, 9-12, Căscioarele, Chirnogi, Târgşor G. 184 - fig. 7: 15 and 253, of which, the pendants were attached either to the string of beads in G. 184, or to the beads sewn on clothes in G. 253); bells (Căscioarele, Largu G. 1, 10, Luciu ${ }^{1}$ - fig. 7: 7); bracelets (four cases: Călăraşi G. 7 - fig. 4: 1, Căscioarele, Dridu-tell G. 2, and, with some doubts, Bucu M. 11). Although for the moment we cannot know whether or not it has a certain significance (as some authors assume for the Roman world - Aparaschivei et al. 2012, p. 176, 177; Aparaschivei 2014, p. 70), it is still worth noting the almost equal number of cases in

1. A bell fragment is mentioned in the inventory of G. 3 from Smeeni-Movila Mare, but given the doubts of the authors (Simache, Teodorescu 1962, p. 279, 280), the absence of any illustration and the association with dagger - the only of this type in Wallachia, I did not take it under consideration. 

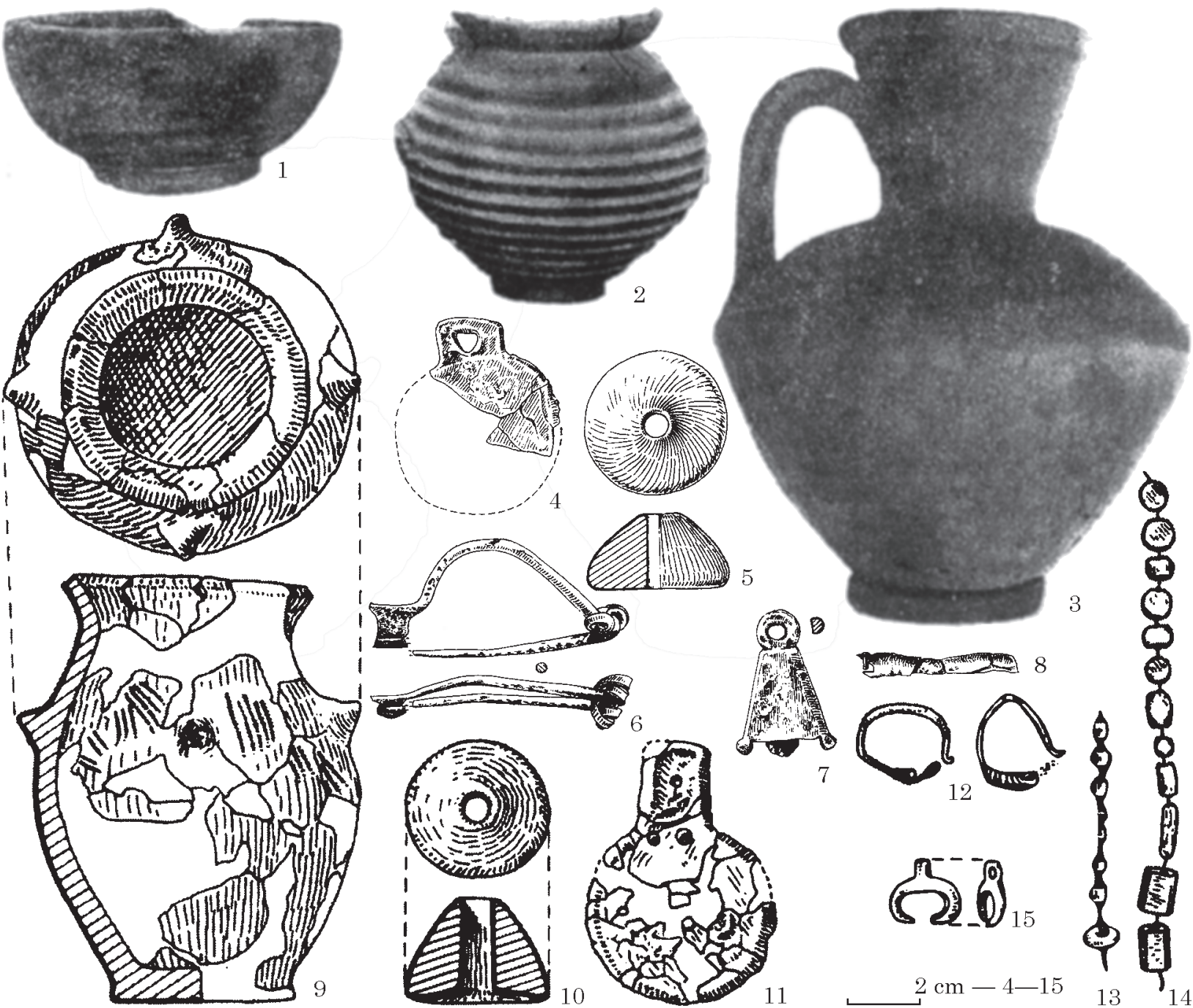

Fig. 7. Sarmatian graves from northeastern and northern Wallachia: $1-8-$ Luciu; 9-15 - Târgşor G. 184 (after: 1—8-Drâmbocianu 1974; 9-15—Diaconu 1965)

which only one earring was found (11 - BrăilaRadu Negru, Bucu G. 11, 14, Călăraşi G. 6, 7, Chiscani-sat, Gălățui G. 2, Grădiştea G. 19, Largu G. 7, Păuleasca G. 3, and if it was indeed an earring, Dridu-tell G. 2) or two (10- Bucu G. 8, Bogdana, Căscioarele, Ciulnița G. 18, Largu G. 8, one grave from Oltenița-Coada Lupului, OltenițaPuțul de Cărămidă G. 1, Sultana G. 2, Târgşor G. 184 and 198). It is also worth mentioning that the two earrings in G. 1 from Oltenita-Putul de Cărămidă, although of the same type, do not belong to the same set, a fact that appears from their visibly unequal dimensions (Muntenia... 2001, nos. 127, 128). In the Sarmatian graves dated to the late $2^{\text {nd }}$ century $\mathrm{AD}$ and the first half of the following century were discovered either a single type of adornment, or several associated types. Where a single type of adornment was found inside the grave, this was prevalently a string of beads (Brăila-Liceu, Ciulnița G. 1B, Gălătui G. 3, Grădiştea G. 11, Largu G. 2, Măriuța G. 2/2009, Oltenița-Renie G. 1, 8, Târgşor G. 206, 267), that sometimes had pendants or bells (Chirnogi, Largu G. 1). One or two earrings were the only adornment in G. 14 from Bucu, Bogdana, G. 6 from Călăraşi, G. 2 from Gălății, G. 8 from Largu, one grave from Oltenița-Coada Lupului, G. 3 from Păuleasca, perhaps in G. 5 from Largu, too, and in the grave from Luciu was found only a bell. The combinations between beads and earrings are attested in six certain cases (Bucu G. 8, Chiscani-sat, Ciulnița G. 18, Largu G. 7, Târgşor G. 184 and 198), a number that could amount to 11 if we would also consider the beads whose position is unknown in G. 1 from Oltenita-Putul de Cărămidă, G. 57 from Păuleasca (in doubt about the fact that the links could have been not necessarily earrings, but pendants or even loop rings), G. 2 from Sultana, G. 19 from Grădiştea, and Brăila-Radu Negru. At least so far, the association between earring and bracelet found in G. 11 from Bucu remains singular. The combination beads + earrings + bracelet is found in three cases, however each time supplemented by another type of adornment: bronze tube perhaps used as a pendant, possibly also link decorated with knobs in G. 2 from Dridu-tell, pendant in G. 7 from Călăraşi, pendant and bell at Căscioarele. 


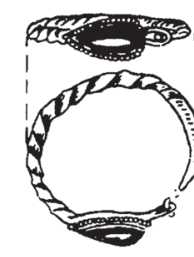

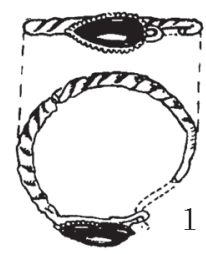

$2 \mathrm{~cm}$
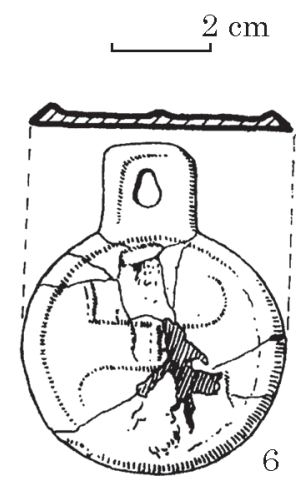
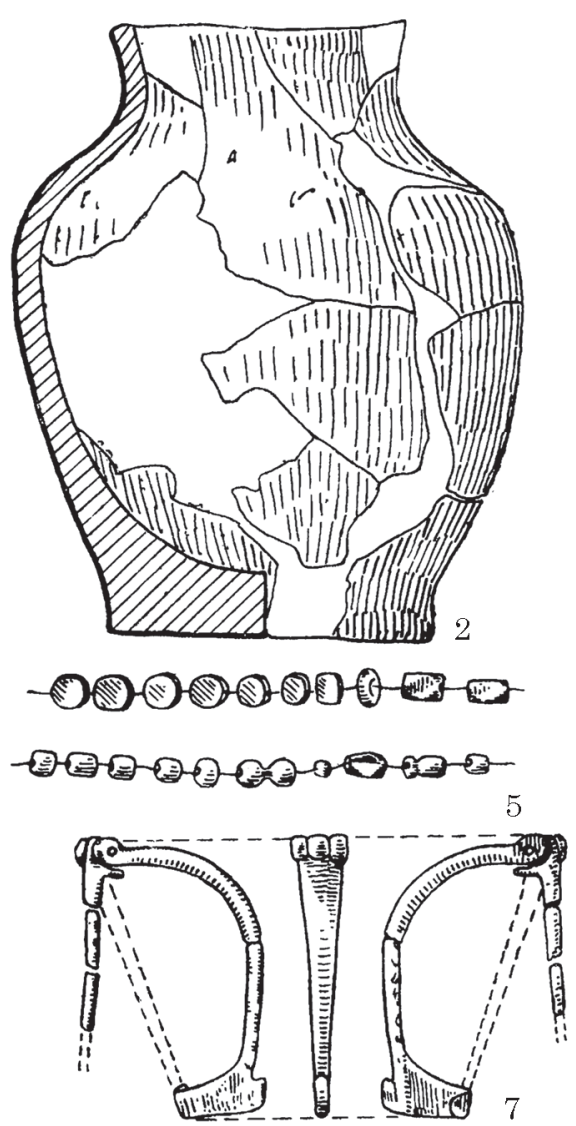
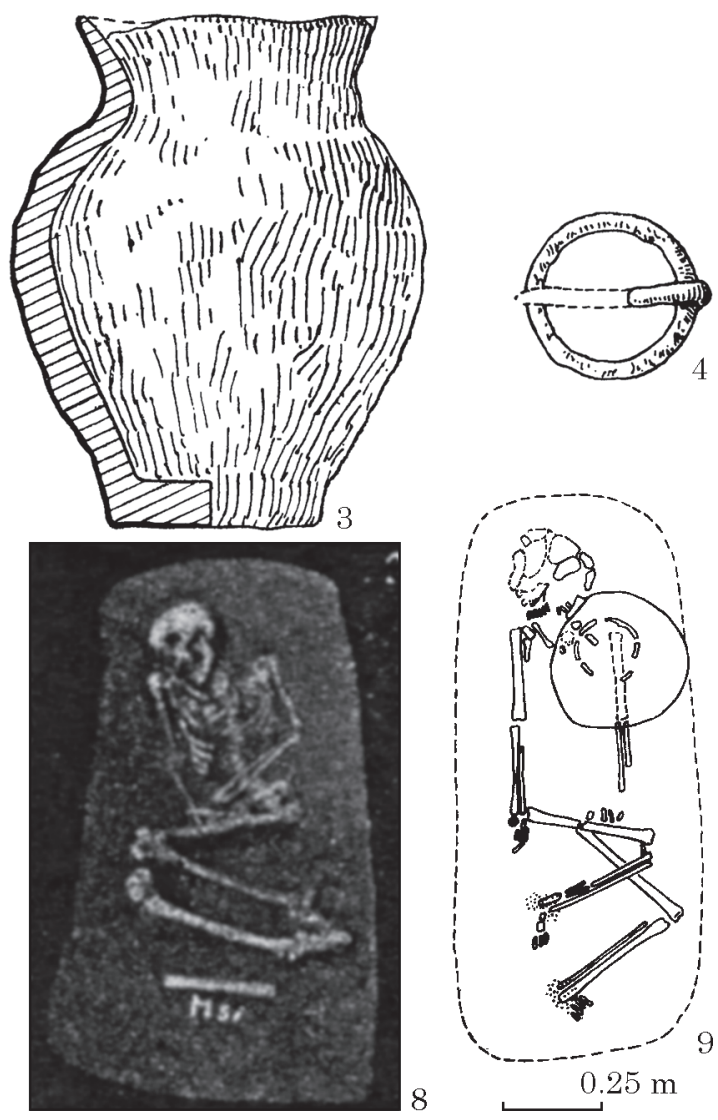

Fig. 8. Sarmatian graves from northern and southern Wallachia: 1-7 - Târgşor G. 198; 8 - Păuleasca G. 57; 9 - Târgşor G. 200 (after: 1-7, 9 - Diaconu 1965; 8 - Bichir 1977)

The number of graves in which dress accessories were found is 23 (in doubt about the uncertainty of the functionality as a buckle of the link found left to the pelvis of the deceased individual in G. 4 from Buzău-sud). The majority of the dress items are brooches (14 cases: Călăraşi G. 7 - fig. 4: 3, Căscioarele, Căzăneşti G. 1, Chiscani-sat - fig. 5: 2, Ciulnița G. 1B - fig. 6: 5 and G. 4, Dorobanțu G. 1 and 5, Largu G. 1, Luciu - fig. 7: 6, Sultana G. 2, Târgşor G. 198 - fig. 8: 7 and G. 411, possibly also Smeeni-Movila Mare G. 2), followed by buckles, in descending order of frequency (Brăila-Hipodrom G. 2 - fig. 3: 6, Bucu G. 8, Ciulnița G. 1B - fig. 6: 4, Târgşor G. 198 - fig. 8: 4, possibly also Buzău-sud G. 4), footgear (Ciulnița G. 1A, Largu G. 6, Smeeni G. 3, Târgşor G. 148, 205), appliqués (Brăila-Radu Negru and Căscioarele), buttons (Largu G. 6) or bronze clasps (Smeeni G. 3).

The number of mirrors deposited inside the graves is surprisingly high -27 cases (BrăilaRadu Negru, Bucu G. 4 and 8, Borduşelu, Bucureşti-Dealul Piscului, Călăraşi G. 1, 3, 6, 7 - fig. 4: 4, Chiscani-sat - fig. 5: 4, Ciulnița G. 1B - fig. 6: 3, Dridu-sat G. 1, Dridu-tell G. 2, Gălățui G. 2, Grădiştea G. 11, Largu G. 1, 7, 9, Luciu - fig. 7: 4, Oltenița-Renie G. 1 and G. 7, Pietroiu, Mihail Kogălniceanu, Târgşor G. 184 fig. 7: 11; G. 198 - fig. 8: 6; G. 200, 411).

The household tools were found in at least 19 graves. Found almost never in the graves of the first stage of Sarmatian settlement in Wallachia (Oța, Sîrbu 2016a, p. 276; 2016b, p. 155), the spindle-whorls were discovered in at least 15 graves of the second stage of arrival of the Sarmatians in Wallachia (Bucu G. 6, Chiscani-sat, Ciulnița G. 1B - fig. 6: 2, Gălățui G. 4, Grădiştea G. 9 - with a surprising number of three spindlewhorls - fig. 5: 8, G. 11, Luciu - fig. 7: 5, at least one funerary structure from Oltenița-Coada Lupului, Oltenița-Iordoc G. 2, 3, Oltenița-Renie G. 7, Smeeni G. 2, Târgşor G. 184 - fig. 7: 10; G. 198, 200). The knives are as rare as in the previous stage - only four cases (Buzău-sud G. 4, Ciulnița G. 3, Grădiştea G. 1, possibly also 9) and the ambivalence of their role (Oța, Sîrbu 2016a, p. 275, $276 ; 2016$ b, p. 155) is also preserved, as they were deposited both in graves of men (Buzău-sud G. 4 and Grădiştea G. 1), and possibly in graves of women, if we take into account the presence of the three spindle-whorls (Grădiştea G. 9). A fishing net weight was found in G. 1 from Buzău-sud.

The weapons deposited in the 10 graves of the second stage are prevalently daggers (eight cases: Bucu G. 10 - fig. 3: 3, Grădiştea G. 1 and 4, Largu G. 4 and 6, Oltenița-Iordoc G. 6, Oltenița-Renie G. 3, Smeeni G. 3), less swords (Brăila-Hipodrom G. 2- fig. 3: 4, 5 and Căzăneşti G. 1). The habit of depositing a single type of weapon inside the grave remains a constant also in the period of time analyzed hereby. However, a few changes can be 


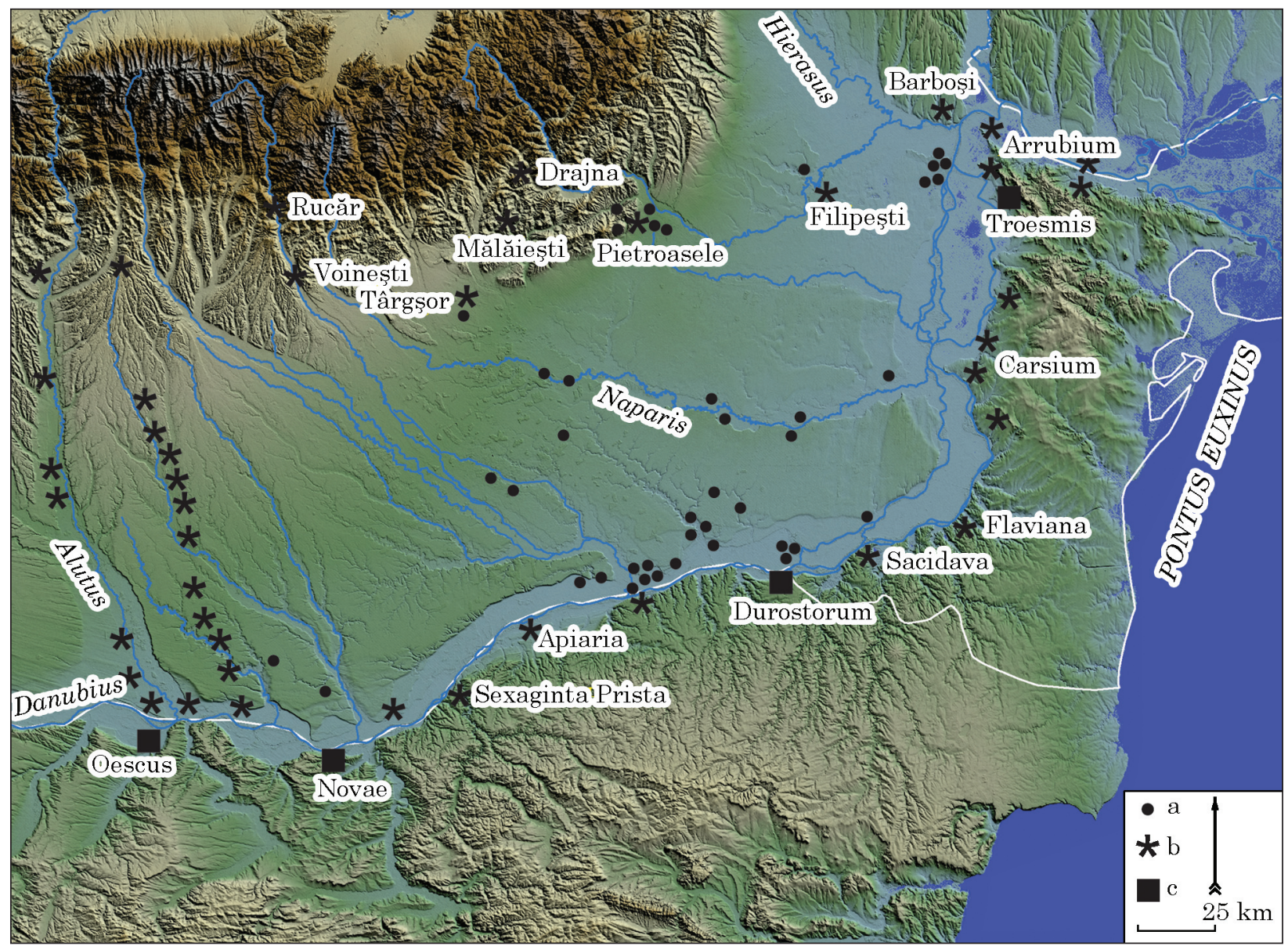

Fig. 9. Second stage of Sarmatian settlement in Wallachia: a - Sarmatian graves; b - Roman fortifications; c - legionary forts (map support provided by Mihai Florea, SRTM-30; mapping by Liana Oța)

detected. Attested in the first stage of arrival of the Sarmatians in Wallachia only in the Brăila Plain (Oța, Sîrbu 2016a, p. 275; 2016b, p. 154), a territorial extension of the burials with weapons in the south of Wallachia in the late $2^{\text {nd }}$ century and in the first half of the $3^{\text {rd }}$ century $\mathrm{AD}$ can be noticed. This territorial extension is not however doubled by an increase in the number of graves in which weapons were deposited, but it records a decrease in their number (during this period the percentage is $6.53 \%$ of the total number of graves and $8 \%$ of the number of graves with inventory, compared to the $18.51 \%$ during the previous period). The number of graves with weapons / group also decreases, so that during this period the maximum number of burials with weapons is two, in the groups from Largu and Grădiştea. The same observation, the standardization of the inventory of graves with weapons (Oța, Sîrbu, Matei 2013, p. 331-333, 335), remains also valid for the analyzed funerary structures; the most common association is weapon + ceramic vessel (Roman bowl in G. 10 from Bucu - fig. 3: 1-3, Dacian wheel-made mugs in G. 4 and 6 from Largu, G. 3 from Smeeni and G. 3 from Oltenița-Renie, vessel of unknown type from Căzăneşti) and two vessels in only one case (Dacian mug and Roman mug in G. 2 from Brăila-Hipodrom - fig. 3: 4-7). Be- sides the dress accessories (brooch in G. 1 from Căzăneşti, belts or footgear in G. 2 from BrăilaHipodrom, G. 6 from Largu, G. 3 from Smeeni, possibly G. 10 from Bucu), the graves with weapons also included knife and fragments of an iron item around the neck (necklace maybe?) in G. 1 from Grădiştea and two beads near the right hand and one bead and two fragments of bronze foil near the left hand in G. 4 from Grădiştea. G. 4 from Largu and G. 6 from Oltenița-Iordoc had only weapon as funerary inventory. In contrast to the tendency to standardize certain features of the funerary ritual, such as the orientation and position of the deceased or the deposit of the pottery, the positions in which the weapons were placed are varied. Preference seems to be given to the deposit on the right side of the deceased (Grădiştea G. 4, Largu G. 4, 6, Smeeni G. 3, Bucu G. 10, Oltenița-Iordoc G. 6 and Oltenița-Renie G. 3), although not always in the position it would have been worn during lifetime (in G. 10 from Bucu, the dagger was deposited near the feet and next to the vessel and in G. 6 from Oltenița-Renie near the right humerus). Only the sword in G. 2 from Brăila-Hipodrom and the dagger in G. 1 from Grădiştea were deposited on the left side, while in this latter case the knife was found on the right side. 
In my opinion, the identification of the item from Luciu (fig. 7: 8) with a fan (Popa 2007, p. 332; 2009, p. 82; Skóra, Niezabitowska-Wiśniewska 2018, p. 164, no. 17) is questionable due to its fragmentary state of preservation (practically, all the characteristic details such as links or joint remains are missing, the item does not seem to have a U-shaped section, instead it is tubular according to the description and it has a transversal rivet at one end which is not observed for the already known fans). Although there are still doubts due to the preservation, I rather believe that the item that was described in the inventory of G. 1B from Ciulnița (fig. 6: 6) as a bronze pendant (Rența 2016, p. 94, fig. 197: 3) made of two rolled sheets with a link at one end could be the handle of a Tălmaza type fan. If indeed the item from Ciulnita is a fan, it would join another one known in G. 8 from Bucu.

The inventory of the graves of the second stage of Sarmatian settlement in Wallachia can be completed with astragals (G. 1 from Jilava and G. 196 from Târgşor), knucklebones (Oltenița-Iordoc G. 4), chalk (Grădiştea G. 9), fragment of antler (Buzău-sud G. 2), spur (Târgşor G. 205) and possibly glass vessel (Olteniț-Renie G. 7, unless it is not just a confusion with the unguentarium from Ulmeni). In the absence of other details, the yellowish granules similar in size and shape to wheat grains that were found in G. 7 and 8 from Largu in the area of the skulls and knees, but below the bones, can only be mentioned without having the possibility to know whether they are accidental presences or intentional deposits.

Main features of the funerary ritual. As far as the funerary ritual allows ${ }^{1}$, the image of the Sarmatian communities which arrived in Wallachia in the late $2^{\text {nd }}$ century and the first half of the following century, although preserves many similarities with the communities that arrived in the above-mentioned territory in the late $1^{\text {st }}$ century $\mathrm{AD}$ and the first decades of the $2^{\text {nd }}$ century, also betrays certain changes, a fact that demonstrates once again the need for a differentiated analysis by areas and time intervals. Compared to the previous period, the number of discoveries not only increased considerably, but it also registered an expansion of the territorial distribution, although taken as a whole, the Sarmatian presence in Wallachia remains relatively low. The tendency to uniform the orientation (in the $\mathrm{N}-\mathrm{S}$ direction) and the position of the deceased individuals (laid out in supine position, with the arms along the body and the legs extended) can be clearly observed. As regards the funerary inventory, not only the diversity of the categories

1. I will not resume here the discussion on the degree to which the funerary ritual really reflects the status that a certain person had during lifetime, a topic that I approached on other occasions (Oța 2018, p. 61; Oța, Sîrbu 2019b, in press). of items is visible, but also their deposit in higher numbers in the funerary structures. A rather marginal phenomenon in the first stage, the deposit of Dacian pottery is registered in the second stage even more often than the deposit of handmade Sarmatian pottery, which could prove that at least the ceramic vessels from the Dacian environment become a common presence for the Sarmatians in Wallachia. Against this background, it seems surprising that, at least judging by the funerary inventory, the Roman imports not only register the same low frequency, but also do not differ too much compared to the previous stage: especially beads, very few ceramic vessels (only 12 graves), earring, bells, three brooches, possibly a glass vessel and, if they really came from the Roman Empire ${ }^{2}$, two fans. I emphasized on other occasions (Oța 2016, p. 141; Oța, Sîrbu 2019b, in press; Sîrbu et al. 2014, p. 118, 119) the change in the display of the social status during the period between the late $2^{\text {nd }}$ century $\mathrm{AD}$ and the middle of the following century, by the disappearance of the tumuli raised especially above a grave (as in Vităneşti), but also by the abandonment of individual burials in older tumuli (except for the grave from Făurei, near Ulmu). The burials in raised forms of land do not disappear completely, but are chosen for groups of graves during this period (10 graves in Largu, six in Ciulnița, three in Jilava, Gălățui and Smeeni-Movila Mare), compared to the only four individual graves (Făurei, Căzăneşti G. 1, Dridu-tell G. 2 and Sudiți), which seems to betray a change of mentality resulting in the loss of the significance of status markers of the tumuli. Certain grave goods seem to preserve their symbolic values in displaying the higher social status in relation to that of the rest of the members of the community. The Roman mug in G. 2 from Brăila-Hipodrom was associated with a Dacian mug and a sword whose handle ended in an opal disc (fig. 3: 4-7), and the Roman bowl in G. 10 from Bucu was found together with a dagger and a bronze bead (fig. 3: 1-3), possibly ornament of a belt. The inventory of the grave from Luciu (fig. 7: 1-8) included three ceramic vessels (one wheel-made Dacian vessel and two of Roman origin), a brooch possibly of Roman origin, bell, mirror, spindle-whorl and another bronze item assumed to be a fan by some researchers. The brooches of possibly Roman origin are part of the numerous and various inventory of the female burials from Călăraşi G. 7 (fig. 4) and Căscioarele. Even if the general tendency is to deposit inside the graves a more numerous and more diversified inventory than in the previous period, several graves draw attention: Brăila-Radu Negru,

2. Kalina Skóra and Barbara Niezabitowska-Wiśniewska (2018, p. 180) believe that fans of Tălmaza type originate from the Black Sea area. Alexandru Popa (2009, p. 90) does not exclude a Roman origin, perhaps not of the items themselves, but of the fashion. 
Călăraşi G. 7 (fig. 4), Căscioarele, Chiscani-sat (fig. 5: 1-6), Ciulnița G. 1B (fig. 6: 2-3, 5-8), Dridu-tell G. 2, Grădiştea G. 9 (fig. 5: 7-10) and 11, Largu G. 1 and 7, Luciu (fig. 7: 1-8), OltenițaRenie G. 7, Târgşor G. 184 (fig. 7: 9-15) and 198 (fig. 8: $1-7$ ). Their characteristic is that all can be attributed to women based on the funerary inventory (also confirmed by the anthropological analysis in some cases). The high number of grave goods is mainly due to the sets of adornments made of strings of beads (in two cases, the beads were not only worn by the deceased females, but even deposited in the vessels, such as the string in G. 7 from Călăraşi and the amber bead in G. 184 from Târgşor), one or two earrings, pendants, bells and sometimes bracelets (Brăila-Radu Negru, Călăraşi G. 7, Căscioarele, Chiscani-sat, Ciulnița G. 1B, Dridu-tell G. 2, Grădiştea G. 11, Largu G. 1 and 7, Târgşor G. 184 and 198). These sets of adornments are added by brooches (Călăraşi G. 7, Căscioarele, Chiscani-sat, Ciulnița G. 1B, Largu G. 1, Târgşor G. 198), mirrors (in all the abovementioned burials except Căscioarele) and, less frequently, spindle-whorls (Chiscani-sat, Ciulnița G. 1B, Grădiştea G. 11, Luciu, Târgşor G. 184 and 198). Another way of assembling the funerary inventory is revealed by G. 9 from Grădiştea, Luciu and G. 7 from Oltenița-Renie, with emphasis not so much on the adornments, but on the large number of vessels or other deposited items (three recipients and three spindle-whorls in Grădiştea G. 9, three vessels, bell, brooch, mirror, spindlewhorl, perhaps a fan at Luciu, seven ceramic vessels and possibly one glass vessel, beads, mirror and spindle-whorl in Oltenița-Renie G. 7.

Following the above discussion, it is important to emphasize two aspects. The first refers to the fact that, against a general background of diversification and increase in the number of items chosen to be deposited inside the grave, a real series of female burials stands out. A possible preference for displaying wealth through women (Palincaş 2013, p. 51), perhaps as a reflection of man's status (Quast 2011, p. 2) cannot be ruled out, especially since, in the case of the double burial in G. 1 from Ciulnița (fig. 6), the funerary inventory of the woman (vessel, string of beads, attire decorated with beads, fan (?), brooch, buckle, mirror, spindle-whorl) contrasts strikingly with the funerary inventory of the man, who had only a small iron item as a possible grave good, because the buckles were from the shoes he was wearing. The second aspect refers to the fact that starting with the late $2^{\text {nd }}$ century $\mathrm{AD}$, the status is displayed without exception not by a special item, but by a combination of several items, which give each other symbolic value either by the type of association (Roman ceramics + weapons), or by the multitude and diversity of the deposited items (pottery, adornments, dress accessories, mirrors, spindle-whorl, fans). The fact that, besides the above-mentioned graves, there are also other burials with associations of adornments such as beads and earrings, toilet implements such as mirrors, but also fashion objects in other cultural environments (fans), which however do not stand out by the accumulation of grave goods indicates that, when judging the social status, it is relevant not so much the type or origin of the items, but the funerary inventory as a whole. From this point of view, the funerary structure from BrăilaLiceu, unique not so much by the type of ceramic recipients, but by the combination of two Roman vessels (pot and cup - fig. 1: 2, 3), would not be an exception.

Even if from an archaeological point of view the interaction with the Roman Empire does not prove to be significant, this impression is contradicted by the fact that the loss of the Roman control over Wallachia resulted in the sudden decrease, until almost extinction, of the number of Sarmatian discoveries here (Oța 2016, p. 145, 146; 2020, p. 421; Oța, Sîrbu 2013, p. 293), as the few Sarmatian graves known so far belong to another cultural and historical context.

\section{CATALOGUE ${ }^{1}$}

\section{Bogdana (comm. of Bogdana, Teleorman} County)

G. (Sîrbu et al. 2014, p. 15, 131, with previous bibliography).

2. Borduşelu (comm. of Ciochina, Ialomița County)

G. (Sîrbu et al. 2014, p. 15, 16, 131, with previous bibliography).

\section{Brăila (Brăila County)}

Hipodrom G. 1 (Oța, Sîrbu 2009, p. 93, nos. IA 1, 2, 117, 191, 192, with previous bibliography), G. 2 (Oța, Sîrbu 2009, p. 15, 16, no. IA 2, 94, 95, nos. IA 3, 4, 117, 191, 192, with previous bibliography), G. 3 (Oța, Sîrbu 2009, p. 13-15, no. IA 1, 95, no. IA 5, 117, 118, 191, 192, with previous bibliography), G. 4 (Oța, Sîrbu 2009, p. 118, 191, 192, with previous bibliography), G. 5 (Oța, Sîrbu 2009, p. 118, 191, 192, with previous bibliography).

\section{Brăila (Brăila County)}

Liceul de Chimie (today Grup şcolar industrial "C. D. Nenițescu») G. (Oța, Sîrbu 2009, p. 16-20, nos. IB 3-5, 118, 191, with previous bibliography).

5. Brăila (Brăila County)

Radu Negru G. (Oța, Sîrbu 2009, p. 95, 96, nos. IB $6-8,118,119$, 191, with previous bibliography).

6. Bucu (comm. of Bucu, Ialomița County)

Pochină G. 1 (Sîrbu et al. 2014, p. 16, 17, 123, with previous bibliography), G. 2 (Sîrbu et al. 2014, p. 17, 123, with previous bibliography), G. 3 (Sîrbu et al.

1. Because the aim of this paper is to analyze the characteristics of the graves belonging to the second stage of Sarmatian settlement in Wallachia, the catalogue represents only an auxiliary working tool. This is the reason why I did not mention in all cases the complete list of bibliographical references regarding the graves, but I chose to cite, when possible, only the synthesis mentioning all the previous bibliography, sometimes added by new references. 
2014 , p. 17, 18, 123, with previous bibliography), G. 4 (Sîrbu et al. 2014, p. 18, 123, with previous bibliography), G. 5 (Sîrbu et al. 2014, p. 18, 123, with previous bibliography), G. 6 (Sîrbu et al. 2014, p. 18, 19, 123, with previous bibliography), G. 7 (Sîrbu et al. 2014, p. 19, 20, 123, with previous bibliography), G. 8 (Sîrbu et al. 2014, p. 20-21, 123, with previous bibliography; Skóra, Niezabitowska-Wiśniewska 2018, p. 162, no. 4), G. 9 (Sîrbu et al. 2014, p. 21, 123, with previous bibliography), G. 10 (Sîrbu et al. 2014, p. 21, 22, 123, with previous bibliography), G. 11 (Sîrbu et al. 2014, p. 22, 23, 123, with previous bibliography), G. 12 (Sîrbu et al. 2014 , p. 23, 123, with previous bibliography), G. 13 (Sîrbu et al. 2014, p. 23, 24, 123, with previous bibliography), G. 14 (Sîrbu et al. 2014, p. 24, 123, with previous bibliography).

\section{Bucureşti (Ilfov County)}

Dealul Piscului G. (Mitrea, Preda 1966, p. 87, no. 11; Tzony 1975, p. 283, 286).

\section{Buzău (Buzău County)}

Sud G. 1 (Drâmbocianu 1981, p. 50, 51), G. 2 (Drâmbocianu 1981, p. 51, 52), G. 3 (Drâmbocianu 1981, p. 52), G. 4 (Drâmbocianu 1981, p. 52, 53), G. 5 (Drâmbocianu 1981, p. 53), G. 6 (Drâmbocianu 1981, p. 53, 54), G. 7 (Drâmbocianu 1981, p. 54).

9. Călăraşi (Călăraşi County)

Aeroport G. 1 (Comşa 2015, p. 147, 149, 157; Oța 2015, p. 121, 134; Sîrbu et al. 2014, p. 24, 25, nos. 4$6 \mathrm{~A}, 131$, with previous bibliography).

10. Călăraşi (Călăraşi County)

G. 2 (Sîrbu et al. 2014, p. 25, nos. 4-6B, 125, with previous bibliography).

11. Călăraşi (Călăraşi County)

Halele Centrale (today Piaț Mare) G. 3 (Sîrbu et al. 2014 , p. 26 , nos. $4-6 \mathrm{C}, 125$, with previous bibliography).

\section{Călăraşi (Călăraşi County)}

Adults Polyclinic (today Independentei str.) G. 4 (Sîrbu et al. 2014, p. 26, 27, nos. 4-6D, 125, with previous bibliography).

\section{Călăraşi (Călăraşi County)}

Flacăra str. and Pompierilor str. intersection G. 6 (Sîrbu et al. 2014, p. 27, nos. 4-6F); G. 7 (Sîrbu et al. 2014 , p. 27-30, nos. 4-6F, 124, 125).

14. Călăraşi (Călăraşi County)

Pompierilor str. G. 8 (Sîrbu et al. 2014, p. 30, nos. 4-6G, 124, 125).

15. Călăraşi (Călăraşi County)

Prefecture court G.9 (Sîrbu et al. 2014, p. 30, nos. 4-6G, 124, 125).

\section{Călăraşi (Călăraşi County)}

Pompierilor str. and Progresului str. intersection G. 10 (Sîrbu et al. 2014, p. 30, 31, nos. 4-6I, 124, 125).

17. Căscioarele (comm. of Căscioarele, Călăraşi County)

Suharna G. (Oța 2015, p. 121-134; Sîrbu et al 2014, p. 31-34, 131, with previous bibliography).

18. Căzăneşti (Ialomița County)

G. (Sîrbu et al. 2014, p. 34-35, 132, with previous bibliography).

19. Cetatea Veche (comm. of Spanțov, Călăraşi County)

G. 1 (Comşa 2015, p. 148, 149; Necrasov, Antoniu 1962 , p. 116, 119; Ota 2015, p. 121-134; Sîrbu et al. 2014 , p. $36,37,125$, with previous bibliography), G. 2 (Sîrbu et al. 2014, p. 37, 125, with previous bibliography).

20. Chirnogi (comm. of Chirnogi, Călăraşi County)
G. (Sîrbu et al. 2014, p. 37, 124, with previous bibliography).

21. Chiscani (comm. of Chiscani, Brăila County)

sat G. (Oța, Sîrbu 2009, p. 24-27, nos. II A 8, 9, 9698, nos. 9-11, 119, 191, with previous bibliography). ty) 22. Chiscani (comm. of Chiscani, Brăila Coun-

Trei Movile G. (Oța, Sîrbu 2009, p. 98-99, nos. II B $12,119,120$, 191, with previous bibliography). ty)

23. Ciulnița (comm. of Ciulnița, Ialomița Coun-

T. II G. 2 (Barnea 1995, p. 282, no. 5; CCA campania 1994, p. 23; Rența 2016, p. 86), G. 3 (Barnea 1995 p. 282, no. 5; CCA campania 1994, p. 23; Rența 2016, p. 86-87), T. III G. 1 (Barnea 1995, p. 282, no. 5; CCA campania 1994, p. 23; Rența 2016, p. 94), G. 4 (Barnea 1995, p. 282, no. 5; CCA campania 1994, p. 23; Rența 2016, p. 95-96), G. 10 (Barnea 1995, p. 282, no. 5; CCA campania 1994, p. 23; Rența 2016, p. 96-97), G. 18 (Barnea 1995, p. 282, no. 5; CCA campania 1994, p. 23; Rența 2016, p. 98).

24. Dorobanțu (comm. of Dorobanțu, Călăraşi County)

G. 1 (Sîrbu et al. 2014, p. 42-43, 128, with previous bibliography), G. 2-4 (Sîrbu et al. 2014, p. 43, 128, with previous bibliography), G. 5 (Sîrbu et al. 2014, p. $43,44,128$, with previous bibliography).

25. Dridu (comm. of Dridu, Ialomita County)

sat G. 1 (Sîrbu et al. 2014, p. 44, 45, no. 17, 18A, 131 , with previous bibliography)

26. Dridu (comm. of Dridu, Ialomita County)

tell (known also as Coșereni-Măgura de la Comana) G. 2 (Lazăr, Ştefan, Vasile 2013, p. 68; Oța, Georgescu, Baltă 2015, p. 143-149; Sîrbu et al. 2014, p. $45-48$, no. 17, 18B, 131, with previous bibliography; Ştefan, Dumitraşcu, Mărgărit 2012, p. 71, 72).

27. Gălățui (comm. of Alexandru Odobescu, Călăraşi County)

Movila Berzei G. 2 (Sîrbu et al. 2014, p. 49, 125, with previous bibliography), G. 3 (Sîrbu et al. 2014, p. 49, 50, 125, with previous bibliography), G. 4 (Sîrbu et al. 2014 , p. 50, 51, 125 , with previous bibliography).

28. Grădiştea (comm. of Grădiştea, Brăila County)

Mormântul Elizei G. 1 (Oța, Sîrbu 2009, p. 120, 121, 192-195, with previous bibliography), G. 4 (Oța, Sîrbu 2009, p. 101, nos. 17, 18, 121, 192-195, with previous bibliography), G. 5 (Oța, Sîrbu 2009, p. 101, 102 , no. 19 , $122,192-195$, with previous bibliography), G. 9 (Oța, Sîrbu 2009, p. 102, 103, nos. 20-22, 121, 192-195, with previous bibliography), G. 11 (Oța, Sîrbu 2009, p. 35-39, nos. VA 19, 20, 103, 104, nos. $23,24,121,122,192-195$, with previous bibliography), G. 12 (Oța, Sîrbu 2009, p. 122, 192-195, with previous bibliography), G. 13 (Oța, Sîrbu 2009, p. 104, no. $25,122,192-195$, with previous bibliography), G. 17 (Oța, Sîrbu 2009, p. 104, 105, nos. 26-28, 122, 192-195, with previous bibliography), G. 18 (Oța, Sîrbu 2009 , p. 122 , 192-195 with previous bibliography), G. 19 (Oța, Sîrbu 2009, p. 32, nos. VA 16-18, 123, 192-195, with previous bibliography).

29. Jilava (comm. of Jilava, Ilfov County)

Măgura Jilavei G. 1 (Bichir 1977, p. 177; Rosetti 1934, p. 208; Tzony 1975, p. 283), G. 2 (Rosetti 1934, p. 209); G. 3 (Rosetti 1934, p. 209).

30. Largu (comm. of Largu, Buzău County)

Cornul Malului G. 1 (Bichir 1972, p. 156; 1977, p. 184; Dragomir 1959, p. 476, 477, 479; Dragomir, Croitoru 2011, p. 40, 41), G. 2 (Dragomir 1959, p. 476, 
477; Dragomir, Croitoru 2011, p. 41), G. 3 (Dragomir 1959, p. 476, 477, 479, 480; Dragomir, Croitoru 2011, p. 41), G. 4 (Bichir 1972, p. 155; 1977, p. 183; Dragomir 1959, p. 476, 477, 480; Dragomir, Croitoru 2011, p. 42), G. 5 (Dragomir 1959, p. 476, 477, 478; Dragomir, Croitoru 2011, p. 42), G. 6 (Bichir 1971, p. 277, 278; 1972 , p. 141,$155 ; 1977$, p. $173,183,184 ; 1985$, p. 1169 , 1170; Dragomir 1959, p. 476, 477, 480, 481; Dragomir, Croitoru 2011, p. 42, 43), G. 7 (Bichir 1972, p. 145; 1977, p. 183 ; 1985, p. 1170; Dragomir 1959, p. 476-481; Dragomir, Croitoru 2011, p. 43, 44), G. 8 (Dragomir 1959, p. 476-478, 481; Dragomir, Croitoru 2011, p. 44, 45), G. 9 (Bichir 1961, p. 260; Dragomir 1957, p. 300, 302), G. 10 (Bichir 1972, p. 156; 1977, p. 184; Dragomir 1957, p. 300, 304; Dragomir, Croitoru 2011, p. 32).

31. Luciu (comm. of Luciu, Buzău County)

Popina pe Balta Mică G. (Bichir 1977, p. 168, 172 , 177, 184, 186; 1985, p. 1166; Drâmbocianu 1974, p. 303-307; Popa 2009, p. 82; Skóra, NiezabitowskaWiśniewska 2018, p. 164, no. 17).

32. Măriuța (comm. of Belciugatele, Călăraşi County)

La Movilă G. 2/2009 (Sîrbu et al. 2014, p. 55-57, 129 , with previous bibliography).

33. Mihail Kogălniceanu (comm. of Mihail Kogălniceanu, Ialomița County)

Crucea Movila Inaltă G. (Sîrbu et al. 2014, p. 57, 58, 131, with previous bibliography).

34. Oltenița (Călăraşi County)

Coada Lupului G. 1-3 (Sîrbu et al. 2014, p. 58, 59, nos. 28-34A, 125, with previous bibliography).

35. Oltenița (Călăraşi County)

Iordoc G. 1 (Sîrbu et al. 2014, p. 59, 60, nos. 2834C, 123-124, with previous bibliography), G. 2 (Sîrbu et al. 2014, p. 60, 123, 124, with previous bibliography), G. 3 (Sîrbu et al. 2014, p. 60, 61, 123, 124, with previous bibliography), G. 4 (Sîrbu et al. 2014, p. 61, 123, 124, with previous bibliography), G. 5 (Sîrbu et al. 2014, p. 61, 62, 123, 124, with previous bibliography), G. 6 (Sîrbu et al. 2014, p. 62, 123, 124, with previous bibliography), G. 7 (Sîrbu et al. 2014, p. 62, 123, 124, with previous bibliography), G. 8 (Sîrbu et al. 2014, p. $62,123,124$, with previous bibliography).

36. Oltenița (Călăraşi County)

Coada Malului G. (Sîrbu et al. 2014, p. 62, nos. 2834D, 121, 122, with previous bibliography).

37. Oltenița (Călăraşi County)

Puțul de cắrămidă G. 1 (Sîrbu et al. 2014, p. 62, 63, nos. 28-34E, 131, with previous bibliography).

38. Oltenița (Călăraşi County)

Renie G. 1 (Sîrbu et al. 2014, p. 63, 64, nos. 28-34F, 121, 122, with previous bibliography), G. 2 (Sîrbu et al. 2014, p. 64, 121, 122), G. 3 (Sîrbu et al. 2014, p. 64, 65, 121, 122 with previous bibliography), G. 4 (Sîrbu et al. 2014, p. 65, 121, 122), G. 5 (Sîrbu et al. 2014, p. 65, 121, 122, with previous bibliography), G. 6 (Sîrbu et al. 2014 , p. $65,66,121,122$, with previous bibliography), G. 7 (Sîrbu et al. 2014, p. 66, 67, 121, 122, with previous bibliography), G. 8 (Sîrbu et al. 2014, p. 67, 68, 121, 122), G. 9 (Sîrbu et al. 2014, p. 68, 121, 122).

39. Păuleasca (comm. of Frumoasa, Teleorman County)

G. 1 (Sîrbu et al. 2014, p. 69, 70, 126, with previous bibliography), G. 23 (Sîrbu et al. 2014, p. 70, 126), G. 26 (Sîrbu et al. 2014, p. 70, 126), G. 2 (Sîrbu et al. 2014, p. 72, 126), G. 3 (Sîrbu et al. 2014, p. 72, 126), G. 57 (Sîrbu et al. 2014, p. 70-72, 126, with previous bibliography).

40. Pietroiu (today Borcea village, Călăraşi County)
Stația de pompare G. (Sîrbu et al. 2014, p. 72, 73, with previous bibliography).

41. Smeeni (comm. of Smeeni, Buzău County)

Movila Mare G. 2 (Frînculeasa et al. 2017, p. 54; Simache, Teodorescu 1962, p. 279), G. 3 (Bichir 1972, p. 155,$156 ; 1977$, p. 183-185; Frînculeasa et al. 2017, p. 54, 55; Simache, Teodorescu 1962, p. 279, 280), G. 10 (Frînculeasa et al. 2017, p. 55; Simache, Teodorescu 1962, p. 279, 280).

ty)

42. Sudiți (comm. of Gherăseni, Buzău Coun-

Movila de la Bălaia G. (Constantinescu 1978, p. 24; Frînculeasa 2010, p. 25, note 13, 29).

43. Sultana (comm. of Mânăstirea, Călăraşi County)

Odaia Vlădichii G. 1 (Sîrbu et al. 2014, p. 75, 125, with previous bibliography), G. 2 (Sîrbu et al. 2014, p. 75, 125, with previous bibliography), G. 3 (Sîrbu et al. 2014 , p. 75 , 125 , with previous bibliography), G. 4 (Sîrbu et al. 2014, p. 75, 76, 125, with previous bibliography).

44. Târgşoru Vechi (comm. of Târgşoru Vechi, Prahova County)

G. 118 (Diaconu 1965, p. 59; Niculescu 2003, p. 193, note 77; Mirițoiu 2003, p. 205, no. 70), G. 148 (Bichir 1977, p. 184; Diaconu 1965, p. 20, 25), G. 184 (Bichir 1972 , p. 156,$161 ; 1977$, p. 184 , $186 ; 1985$, p. 1171 ; Diaconu 1965, p. 20, 22, 24, 26, 28; Mirițoiu 2003, p. 205, no. 70), G. 196 (Diaconu 1965, p. 21; Miritoiu 2003, p. 205, no. 70), G. 198 (Bichir 1972, p. 161; 1977, p. 184, 186; Diaconu 1965, p. 21-26, 28), G. 200 (Bichir 1971, p. 277; 1972, p. 141, 161; 1977, p. 172, 186; 1985, p. 1168; Diaconu 1965, p. 19, 21, 24; Miritoiu 2003, p. 205, no. 70), G. 205 (Bichir 1977, p. 184; Diaconu 1965, p. 21, 25, 28; Mirițoiu 2003, p. 205, no. 70), G. 206 (Diaconu 1965, p. 21), G. 208 (Diaconu 1965, p. 21), G. 219 (Diaconu 1965, p. 16, 21), G. 220 (Bichir 1971 , p. $277 ; 1972$, p. $144 ; 1977$, p. $173 ; 1985$, p. 1168 ; Diaconu 1965, p. 19, 21), G. 227 (Diaconu 1965, 21), G. 227 (Diaconu 1965, p. 21), G. 228 (Diaconu 1965, p. 21), G. 253 (Diaconu 1965, p. 22, 28), G. 255 (Diaconu 1965, p. 22), G. 261 (Diaconu 1965, p. 19, 22, 23), G. 267 (Diaconu 1965, p. 22), G. 274 (Diaconu 1965, p. 19, 22; Mirițoiu 2003, p. 205, no. 70), G. 411 (Niculescu 2003, p. 186, 188, note 50, 195), G. 415 (Niculescu 2003, p. 193), G. 433 (Barnea 1991, p. 263, no. 34), G. 435 (Barnea 1991, p. 263, no. 34).

45. Ulmu (comm. of Ulmu, Călăraşi County)

G. 1 (Sîrbu et al. 2014, p. 84, nos. 42-43A, 131, with previous bibliography).

near Făurei village G. 1 (Sîrbu et al. 2014, p. 84, nos. 42, 43B, 131).

46. Vlad Țepeş (comm. of Vlad Țepeş, Călăraşi County)

G. 1 (Sîrbu et al. 2014, p. 89, with previous bibliography), G. 2 (Sîrbu et al. 2014, p. 89, 90, with previous bibliography).

English version A. DECU

\section{REFERENCES}

Aparaschivei, D., Iacob, M., Soficaru, A., Parachiv, D. 2012. Aspects of everyday life in Scythia Minor reflected in some funerary discoveries from Ibida (Slava Rusă, Tulcea County). In: Kogălniceanu, R., Curcă, R.-G., Gligor, M., Stratton, S. (eds.). Homines, Funera, Astra. Proceedings of the International Symposium on Funerary Anthropology, 5-8 June 2011, "1 Decembrie 1918" University (Alba Iulia, România). British Archaeological Reports International Series, 2410. Oxford: Archaeopress, p. 163-168. 
Aparaschivei, D. 2014. Trecerea de la copilărie la maturitate şi rolul căsătoriei în nord-estul provinciei romane Moesia Inferior (Scythia Minor). Arheologia Moldovei, XXXVII, p. 63-72.

Barnea, Al. 1991. Cronica cercetărilor arheologice efectuate în 1990 de Institutul de Arheologie Bucureşti. Studii şi Cercetări de Istorie Veche si Arheologie, 42, 3-4, p. 255-264.

Barnea, Al. 1995. Cronica cercetărilor arheologice efectuate în 1994 de Institutul de Arheologie "Vasile Pârvan» din București. Studii şi Cercetări de Istorie Veche şi Arheologie, 46, 3-4, p. 281-290.

Bernbeck, R., Cubasch, U., Gass, A., Kaiser, E., Parzinger, H., Pollock, S., Rowland, J., Russo, E., Schier, W., Tassie, G. 2016. Notes for a Political Ecology of Non-Sedentary People. eTopoi. Journal for Ancient Studies, special 6: Space and Knowledge. Topoi Research Group Articles, p. 45-73.

Bichir, Gh. 1961. Unele observații cu privire la necropolele de tip Poieneşti din Moldova şi relațiile acestor necropole cu lumea sarmată. Studii şi Cercetări de Istorie Veche, XII, 2 , p. 253-271.

Bichir, Gh. 1971. Les Sarmates sur le territoire de la Roumanie. In: Actes du VIII Congrès des Sciences Préhistoriques et Protohistoriques. Beograd, 9-15 septembre 1971. I: Rapports généraux. Beograd: UISPP, p. 275-285.

Bichir, Gh. 1972. Sarmații la Dunărea de Jos în lumina ultimelor cercetări. Pontica, V, p. 137-176.

Bichir, Gh. 1977. Les Sarmates au Bas-Danube. Dacia, XXI, p. 167-197.

Bichir, Gh. 1985. Sarmatii si relatiile lor cu geto-dacii (II). Revista de Istorie, 38, 12, p. 1164-1177.

CCA campania 1994. Cronica cercetărilor arheologice din România, campania 1994. Cluj-Napoca: Ministerul Culturii.

Ciupercă, B., Măgureanu, A., Anton, A. 2015. The Presence of Rome in Barbaricum: Archaeological Evidence of the Interaction between Romans and Barbarians in the Târgşoru Vechi Area. Bulletin of the National Archaeological Institute, XLII: Limes XXII. Proceedings of the 22nd International Congress of Roman Frontier Studies. Ruse, Bulgaria, September 2012 , p. 771-780.

Comşa, A. 2015. An overview regarding the anthropological investigations about the Sarmatians in the Muntenia and Moldova funerary finds. Arheologia mileniului I p. Chr. IV: Nomazi şi autohtoni în mileniul I p. Chr. In memoriam Maria Comşa, p. 145-165.

Comsa, E. 1989. Mormintele cu ocru din movila II — 1943 de la Ploieşti-Triaj. Thraco-Dacica, X, p. 181-188.

Constantinescu, M. 1978. Un mormânt din perioada migrațiilor, descoperit la Balta Albă, județul Buzău. Mousaios, 2 , p. $22-25$.

Dan, A. 2017. The Sarmatians: Some Thoughts on the Historiographical Invention of a West Iranian Migration. In: Wiedermann, F., Hofmann, K. P., Gehrke, J. (eds.). Vom Wandern der Völker. Migrationserzählungen in den Altertumswissen schaften. Berlin Studies of the Ancient World. Berlin: Topoi, p. 97-134.

Diaconu, Gh. 1965. Tîrgsor - Necropola din secolele IIIIV e. n. Biblioteca de Arheologie, VIII. Bucureşti: Academia.

Dragomir, I. T. 1957. Vestigii arheologice pe valea Călmățiului. Materiale şi Cercetări Arheologice, III, p. 300310.

Dragomir, I. T. 1959. Raport asupra săpăturilor întreprinse la Largu (r. Filimon Sîrbu, reg. Galați). Materiale și Cercetări Arheologice, V, p. 475-482.

Dragomir, I. T., Croitoru, C. 2011. La nécropole sarmatique de Largu (dép. de Buzău). Istros, XVII, p. 31-54.

Drâmbocianu, V. 1974. Un mormânt sarmatic descoperit la Luciu (jud. Buzău). Studii şi Cercetări de Istorie Veche şi Arheologie, 25, 2, p. 303-307.

Drâmbocianu, V. 1981. Şantierul arheologic de salvare din punctul Buzău-sud. Mousaios, 3, p. 50-57.

Frachetti, M. D. 2011. Migration Concepts in Central Eurasian Archaeology. Annual Review of Anthropology, 40, p. $195-212$

Frînculeasa, A. 2010. Noi informații privind cercetările arheologice de la Sudiți, com. Gherăseni (jud. Buzău) - descoperiri din epoca neo-eneolitică. Mousaios, XV, p. 23-54.

Frînculeasa, A., Simalcsik, A., Preda, B., Garvăn, D 2017. Smeeni - Movila Mare. Monografia unui sit arheologic regăsit. Târgovişte: Cetatea de Scaun.
Kradin, N. N. 2015. The Ecology of Inner Asian Pastoral Nomadism. In: Kardulias, P. N. (ed.). The Ecology of Pastoralism. Boulder: University Press of Colorado, p. 41-70.

Lazăr, C., Ene, D., Parnic, V., Popovici, D. N., Florea, M. 2011. Ground Penetrating Radar Prospections in Romania. Măriuta-La Movilă Necropolis, a Case Study. Mediterranean Archaeology and Archaeometry, 11, 2, p. 79-89.

Lazăr, C., Ştefan, C. E., Vasile, G. 2013. Considerații privind resturile osteologice umane din cadrul unor aşezări eneolitice din sud-estul României. Studii de Preistorie, 10, p. 6788.

Leahu, V., Trohani, G. 1979. Săpăturile arheologice de la Vităneşti, jud. Teleorman. Cercetări Arheologice, III, p. 127141.

Miritoiu, N. 2003. Sarmatische Gräber mit künstlich deformierten Schädeln in Muntenien. In: Kontakt-KooperationKonflikt. Germanen und Sarmaten zwischen dem 1. und dem 4. Jahrhundert nach Christus. Internationales Kolloquium des Vorgeschichtlichen Seminars der Philipps-Universität Marburg, 12.-16. Februar 1998. Neumünster: Wachholtz, S. 204-205.

Mitrea, B., Preda, C. 1966. Necropolele din secolul al IV-lea e. n. in Muntenia. Bucuresti: Academia.

Mordvintseva, V. 2013. The Sarmatians: The Creation of Archaeological Evidence. Oxford Journal of Archaeology, 32, 2, p. 213-219

Mordvintseva, V. I. 2015. Sarmaty, Sarmatiia i Severnoe Prichernomore. Vestnik drevnei istorii, 1, p. 109-135.

Mordvintseva, V. 2016. Barbarians of the North-Pontic Region and Their Contacts with Centres of the Antique Civilization from the $3^{\text {rd }}$ Century BCE to the Mid $3^{\text {rd }}$ Century CE (According to the Research of the Elite Barrows). In: Cojocaru, V., Rubel, A., Stah, D. and Castelli, T. (eds.). Mobility in Research of the Black Sea Region. Pontica et Mediterranea, VI. Cluj-Napoca: Mega, p. 387-438.

Morintz, S., Ionescu, B. 1968. Cercetări arheologice în împrejurimile oraşului Oltenița (1958-1967). Studii şi Cercetări de Istorie Veche, 19, 1, p. 95-128.

Morintz, S., Ionescu, B. 1970. Mormintele sarmatice din sud-estul județului Ilfov. In: Florescu, R., Pavel, A. (eds.). Sesiunea de Comunicări a Muzeelor de Istorie 1964, II. Biblioteca Muzeelor, VII. Bucuresti: Grafica Nouă, p. 37-54.

Muntenia... 2001. Muntenia in secolele II-IVp. Chr. Catalog expozitie 18 octombrie - 30 noiembrie 2001, Muzeul Municipiului Bucureşti. Bucureşti: Muzeul Municipiului Bucureşti.

Necrasov, O., Antoniu, S. 1962. Sur un crâne présentant une déformation «macrocéphale», découvert a Tatina-Spanțov. Analele Ştiințifice ale Universității Iaşi, 8, 1, p. 115-119.

Nestor, I. 1944. Raport asupra săpăturilor şi cercetărilor din campania anului 1943. In: Raport asupra activității stiintifice a M. N. A. în anii 1942 si 1943. Bucuresti, p. 55-56.

Niculescu, Gh. Al. 2003. Die sarmatische Kultur im Zusam. menhang der kaiserzeitlichen archäologischen Funde aus Muntenien - unter besonderer Berücksichtigung der Funde von Tîrgşor. In: Kontakt-Kooperation-Konflikt. Germanen und Sarmaten zwischen dem 1. und dem 4. Jahrhundert nach Christus. Internationales Kolloquium des Vorgeschichtlichen Seminars der Philipps-Universität Marburg, 12.-16. Februar 1998. Neumünster: Wachholtz, S. 177-205.

Olbrycht, M. J. 2000. Notes on the presence of Iranian peoples in Europe and their Asiatic relations. In: Pstrusińska, J., Fear, A. (eds.). Collectanea Celto-Asiatica Cracoviensia. Kraków: Ksiegarnia Akademicka, p. 101-140.

Opreanu, C. 1994. Neamurile barbare de la frontierele Daciei si relatiile lor politico-diplomatice cu Imperiul. Ephemeris Napocensis, IV, p. 193-220.

Opreanu, C. H., Lăzărescu, V. A. 2016. The limes as a contact zone between Orbis Romanus and Barbaricum. In: Opreanu, C. H., Lăzărescu, V. A. (eds.). Landscape Archaeology on the Northern Frontier of the Roman Empire at Porolissum. An interdisciplinary research project. Cluj-Napoca: Mega, p. 4348.

Ota, L. 2014-2015. Observations on the Sarmatian Graves in Wallachia in which Hand-made Pottery Was Deposited. Thraco-Dacica, VI-VII (XXIX-XXX), p. 95-118.

Oța, L. 2015. Despre mormintele aparținând unor indiviz cu cranii deformate la sarmații din Muntenia şi Moldova. Ar- 
heologia mileniului I $p$. Chr. IV: Nomazi si autohtoni în mileniul I p. Chr. In memoriam Maria Comşa, p. 119-144.

Ota, L. 2016. Beyond the Lower Danubian Limes - Sarmatians and Romans. In: Alexandrescu, C. G. (ed.). Troesmis - A Changing Landscape. Romans and the Others in the Lower Danube Region in the First Century BC - Third Century AD. In: Proceedings of an International Colloquium, Tulcea $\left(7^{\text {th }}-10^{\text {th }}\right.$ of October 2015). Cluj-Napoca: Mega, p. 129 150.

Oța, L. 2018. Sarmatian Children Graves in Wallachia and Moldavia. Tyragetia, XII (XXVII), 1, p. 41-70.

Oța, L. 2020. Câteva observații despre descoperirile arheologice din secolul al III-lea p. Chr. în Muntenia. In: Cândea, I. (ed.). The Thracians and their neighbours in antiquity: archaeology and history. Studies in honor of Valeriu Sîrbu at his $70^{\text {th }}$ anniversary. Brăila: Istros a Muzeului Brăilei «Carol I», p. 417-442.

Oța, L., Comşa, A. 2012. Un mormânt sarmatic descoperit la Călăraşi. Materiale şi Cercetări Arheologice, VIII, p. 97106.

Oța, L., Georgescu, M., Baltă, Z. I. 2015. Despre cele două morminte din tell-ul de la Dridu. Materiale şi Cercetări Arheologice, XI, p. 143-156.

Oța, L., Sîrbu, V. 2009. Sarmații din județul Brăila. Brăila: Muzeul Brăilei, Istros.

Oța, L., Sîrbu, V. 2012. La céramique dacique dans les tombes sarmatiques de Valachie. Istros, XVIII, p. 125-163.

Oța, L., Sîrbu, V. 2013. The Bărăgan in the $1^{\text {st }}-3^{\text {rd }}$ Centuries AD: Dacians, Romans, Sarmatians. In: "Necropolises, Cult places, Religion, Mythology" - The Thracians and their Neighbors in the Bronze and Iron Ages. Proceedings of The $12^{\text {th }}$ International Congress of Thracology, Târgovişte, $10^{\text {th }}-14^{\text {th }}$ September 2013, II. Braşov: Istros, p. 289-309.

Oța, L., Sîrbu, V. 2016a. The early settlement of Sarmatians in Wallachia. Tyragetia, X (XXV), 1, p. 261-284.

Ota, L., Sîrbu, V. 2016b. Prima etapă de pătrundere a sarmaților în Muntenia. Acta Musei Tutovensis. Istorie veche şi arheologie, XII, 2, p. 147-167.

Ota, L., Sîrbu, V. 2016c. Aproape de limes - Sarmatii din Muntenia, Moldova, Crişana şi Banat. Istros, XXII: Proceedings of the $15^{\text {th }}$ International Colloquium of Funerary Archaeology «Interdisciplinary Methods of Research for Prehistoric and Protohistoric Funerary Monuments». Brăila, $20^{\text {th }}-22^{\text {nd }}$ May 2016. p. 205-255.

Oța, L., Sîrbu, V. 2019a. Only By Chance? Sarmatians, Romans, Dacians in Wallachia and Moldavia. In: Sîrbu, V., Schuster, C., Hortopan, D. (eds.). Border Guards of the Passes, from the Fortresses and the Graves. The Bronze and Iron Ages. Proceedings of the $17^{\text {th }}$ International Colloquium of Funerary Archaeology, Târgu Jiu, Gorj County (Romania), $4^{\text {th }}-7^{\text {th }}$ October 2018. Târgu Jiu; Brăila: Istros a Muzeului Brăilei «Carol I», p. 149-174.

Ota, L., Sîrbu, V. 2019b. Funerals and Social Status at the Sarmatians from a Border Area: Wallachia and Moldavia. Mousaios, 23: Bronze and Iron Age in Eurasia: Rituals and Grave Goods as Possible Markers of the Social Identity of the Dead. Proceedings of The $18^{\text {th }}$ International Colloquium on Funerary Archaeology, Buzău, 17 $7^{\text {th }}-20^{\text {th }}$ October 2019 (in press).

Oța, L., Sîrbu, V., Matei, S. 2013. «Male» and «female» grave-goods in Sarmatian tombs found in Wallachia. Mousaios, XVIII: Bronze and Iron Age Graves from Eurasia Gender between Archaeology and Anthropology. Proceedings of the $13^{\text {th }}$ International Colloquium of Funerary Archaeology, Buzău-Romania, $17^{\text {th }}-21^{\text {st }}$ October 2012, p. 325-352.

Palincas, N. 2013. Animals and the making of gender in the later period of the Monteoru culture (Subcarpathian Arc between ca. 1700 and $1500 \mathrm{cal} \mathrm{BC).} \mathrm{Mousaios,} \mathrm{XVIII:} \mathrm{Bronze}$ and Iron Age Graves from Eurasia - Gender between Archaeology and Anthropology. Proceedings of the $13^{\text {th }}$ International Colloquium of Funerary Archaeology, Buzău-Romania, $17^{\text {th }}-21^{\text {st }}$ October 2012 , p. $43-78$.

Petolescu, C. C. 2010. Dacia: un mileniu de istorie. Bucureşti: Academia Română.

Popa, Al. 2007. Flabella im Barbaricum? Überlegungen zu einer Fundgruppe bronzener Gegenstände aus dem Gebiet Jenseits der Provinzen Dacia und Moesia Inferior. Germania, 85, p. 329-347.
Popa, Al. 2009. Consemnări asupra mormântului de la Tălmaza şi a inventarului lui. Notă despre răspândirea evantaielor romane în barbaricum-ul european. Ephemeris $N a$ pocensis, XIX, p. 79-108.

Przybyła, M. 2011. Migration of individuals in the Roman period. Testimonies of fine female dress in Scandinavia. Acta Archaeologica, 82, p. 227-251.

Quast, D. 2011. Weibliche Eliten - Eine Einführung. In: Weibliche Eliten in der Frühgeschichte. Internationale Tagung vom 13. bis 14. Juni 2008 im RGZM im Rahmen des Forschungsschwerpunktes "Eliten». Mainz: RGZM, S. 1-4.

Rența, E. 2000. Necropola sarmatică de la Bucu, județul Ialomița. Ialomița, III, p. 39-57.

Renta, E. 2016. Cercetările arheologice de salvare de la Ciulnița, județul Ialomița (1994-1997). Așezarea neolitică Boian-Giuleşti, tumulii I-III şi alte descoperiri din eneolitic, epoca bronzului și epoca fierului. Muzeul Judetean Ialomița, Seria Situri Arheologice, V. Târgovişte: Cetatea de Scaun.

Rosetti, D. V. 1934. Siedlungen der Kaiserzeit und der Völkerwanderungszeit bei Bukarest. Germania, 18, 3, S. 208209.

Rustoiu, A. 2008. Celții din Transilvania şi comunitățile indigene nord-balcanice. Schimburi culturale şi mobilitate individuală. Ephemeris Napocensis, XVIII, p. 25-44.

Simache, N., Teodorescu, V. 1962. Săpăturile arheologice de salvare de la Smeieni (r. Buzău, reg. Ploieşti). Materiale şi Cercetări Arheologice, VIII, p. 273-281.

Sîrbu, V., Oța, L., Vîlcu, A., Neagu, M., Oprea, V. 2014. Sudul Munteniei in secolele I a. Chr. - III p. Chr. Sarmați, daci, romani. Brăila: Muzeul Brăilei «Carol I», Istros.

Skóra, K., Niezabitowska-Wiśniewska, B. 2018. Flabellum czy calamistrum? I jeszcze jeden, niezwykle intrygujący zabytek... z Dratowa. In: Niezabitowska-Wiśniewska, B., Łuczkiewicz, P., Sadowski, S., Stasiak-Cyran, M., Erdrich, M. (eds.). Studia Barbarica. For Professor Andrzej Kokowski on His $75^{\text {th }}$ Birthday, II. Lublin: Akapit, p. 130-180.

Suceveanu, Al. 2000. La céramique romaine des $I^{e r}$ II siècles ap. J.-C. Histria, X. Bucarest: CIMEC.

Stefan, C. E., Dumitraşcu, V., Mărgărit, M. 2012. Restitutiones Archaeologicae: aşezarea de tip tell de la Coşereni «Măgura de la Comana», jud. Ialomița. Buletinul Muzeului Judetean Teleorman, Seria Arheologie, 4, p. 71-100.

Theuws, F. 2009. Grave goods, ethnicity, and the rhetoric of burial rites in Late Antique Northern Gaul. In: Derks, T. Roymans, N. (eds.). Ethnic Constructs in Antiquity. The Role of Power and Tradition. Amsterdam Archaeological Studies, 13. Amsterdam: Amsterdam University Press, p. 283-319.

Tzony, M. 1975. Morminte sarmatice descoperite la Mogoşoaia-sat şi Dealul Piscului-Bucureşti. Studii şi Cercetări de Istorie Veche şi Arheologie, 26, 2, p. 283-288.

Țentea, O. 2013, Despre frontiera Dunării de Jos în timpul Principatului. Cercetări Arheologice, XX, p. 143-154.

Vulpe, Al. 1987. Varia archaeologica (I). Descoperirile hallstattiene de la Ploieşti-«Triaj». Thraco-Dacica, VIII, p. 177191.

Wendrich, W., Barnard, H. 2008. The archaeology of mobility: definitions and research approaches. In: Barnard, H., Wendrich, W. (eds.). The archaeology of mobility: old world and new world nomadism. Los Angeles: Cotsen Institute of Archaeology, University of California, p. 1-21.

\section{Oța}

\section{THE SECOND STAGE OF SARMATIAN SETTLEMENT IN WALLACHIA}

The aim of this paper is to discuss the features of the graves that can be attributed to the second stage of Sarmatian settlement in Wallachia. The first stage of arrival of the Sarmatians in Wallachia can be dated in the last decade of the $1^{\text {st }}$ century $\mathrm{AD}$ and the first decades of the $2^{\text {nd }}$ century $\mathrm{AD}$. The second stage of arrival of the Sarmatians in Wallachia, linked to the Marcomannic Wars, begins in the late $2^{\text {nd }}$ century AD and continues during the following century. Sarma- 
tians entered Wallachia not as enemies of the Roman Empire, but as allies always supervised by the Roman troops. A number of 153 graves can be linked with the second stage of Sarmatian settlement in Wallachia, whose territorial distribution, although extended in comparison with the first stage, does not uniformly cover the entire territory of Wallachia. The features of Sarmatian burials are discussed in detail: grave layout (types of interments, orientation, position of the deceased, age and sex of the individuals), main categories of grave goods (pottery, adornments, dress accessories, toilet implements, household tools, weapons). Based on this analysis, the main features of the funerary ritual are emphasized. The tendency to uniform the orientation and the position of the deceased individuals can be clearly observed. As regards the funerary inventory, not only the diversity of the categories of items is visible, but also their deposit in higher numbers in the burials. Dacian pottery is deposited even more often than the handmade Sarmatian pottery, but the Roman imports not only register the same low frequency, but also do not differ too much compared to the previous stage. A clear change in the display of the status during the period between the late $2^{\text {nd }}$ century $\mathrm{AD}$ and the middle of the following century can be noticed: the tumuli lose their significance as status markers, grave goods with significant value disappear, possible higher status is emphasized by association of several items. Against a general background of diversification and in crease in the number of items chosen to be deposited inside the grave, a real series of female burials stands out. The loss of the Roman control over Wallachia resulted in the sudden decrease, until almost extinction, of the number of Sarmatian discoveries here.

Keywords: Sarmatians, Wallachia, Roman Empire, graves, funerary ritual, grave goods.

\section{Л. Ou,}

\section{ДРУГИЙ ЕТАП САРМАТСЬКОГО ПЕРЕБУВАННЯ У ВАЛАХІЇ}

Метою даної роботи є дослідження поховань, які можна віднести до другого етапу сарматської культури у Валахії. Перший період появи сарматів у Валахії може бути датований останнім десятиліттям I ст. н. е. та першими десятиліттями II ст. н. е. Другий етап перебування сарматів у Валахії, пов'язаний з Маркоманськими війнами, починаеться наприкінці II ст. н. е. і тривае протягом наступного століття. Сармати увійшли у Валахію не як вороги Римської імперії, а як союзники, яких завжди контролювали римські війська. Добірку з 153 поховань можна пов'язати 3 другим етапом сарматського перебування у Валахії, територіальне поширення якого, хоча і розширене порівняно з першим етапом, не охоплює однаково всю територію Валахії. Детально досліджуються особливості сарматських поховань: розміщення могил (типи поховань, орієнтація, положення померлого, вік та стать осіб), основні категорії поховального начинння (кераміка, прикраси, аксесуари одягу, предмети туалету, господарські інструменти, зброя). На основі цього аналізу підкреслюються основні риси поховального ритуалу. Чітко спостерігається тенденція до уніфікації орієнтації та позиції померлих. Що стосуеться поховального інвентарю, наявна не лише різноманітність категорій предметів, але й більша їх кількість у похованнях. Дакійська кераміка вміщуеться до могил навіть частіше, ніж ліпна сарматська кераміка, але римський імпорт стабільно рідкісний, що не надто відрізняеться від попереднього етапу. Можна помітити чітку зміну відображення статусу в період між кінцем II ст. н. е. і серединою наступного століття: кургани втрачають своє значення як маркери статусу, коштовний поховальний інвентар зникає, можливий вищий статус підкреслюеться значущістю декількох предметів. На загальному тлі диверсифікації та збільшення кількості предметів, обраних для поховальних дарунків, виділяється серія жіночих поховань. Втрата римського контролю над Валахіею призвела до раптового зменшення, майже до зникнення тут сарматських знахідок.

Ключові слова: сармати, Валахія, Римська імперія, могили, поховальний ритуал, поховальне начиння.

Одержано 28.05.2020

ОЦА Ліана Лоредана, кандидат історичних наук, старший науковий співробітник, Інститут археології «Василе Пирван», Румунська академія наук, вул. Хенрі Коанде, сектор 1, Бухарест, 010667, Румунія.

OȚA Liana, Dr., Senior Researcher, «Vasile Pârvan», Institute of Archaeology, Romanian Academy, 11, Henri Coandă Str., Sector 1, Bucharest, 010667, Romania. ORCID: 0000-0002-2074-175X, e-mail: loredanaota@ yahoo.com, loredanaota@gmail.com. 